Chicago-Kent College of Law

Scholarly Commons @ IIT Chicago-Kent College of Law

$12-31-2012$

\title{
Unique Proposals for Limiting Legal Liability and Encouraging Adherence to Ventilator Allocation Guidelines in an Influenza Pandemic
}

Valerie Gutmann Koch

IIT Chicago-Kent College of Law, valeriegutmannkoch@gmail.com

Follow this and additional works at: https://scholarship.kentlaw.iit.edu/fac_schol

Part of the Health Law and Policy Commons

\section{Recommended Citation}

Valerie Gutmann Koch, Unique Proposals for Limiting Legal Liability and Encouraging Adherence to Ventilator Allocation Guidelines in an Influenza Pandemic, 14 DePaul J. Health Care L. 467 (2012).

Available at: https://scholarship.kentlaw.iit.edu/fac_schol/783

This Article is brought to you for free and open access by the Faculty Scholarship at Scholarly Commons @ IIT Chicago-Kent College of Law. It has been accepted for inclusion in All Faculty Scholarship by an authorized administrator of Scholarly Commons @ IIT Chicago-Kent College of Law. For more information, please contact jwenger@kentlaw.iit.edu, ebarney@kentlaw.iit.edu. 


\title{
UNIQUE PROPOSALS FOR LIMITING LEGAL LIABILITY AND ENCOURAGING ADHERENCE TO VENTILATOR ALLOCATION GUIDELINES IN AN INFLUENZA PANDEMIC
}

\author{
Valerie Gutmann Koch, J.D. ${ }^{*} \&$ Beth E. Roxland, J.D., M.Bioethics ${ }^{* *}$
}

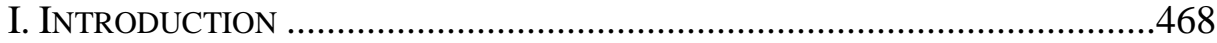

II. EMERGENCY DECLARATIONS AND EXECUTIVE ORDERS ..........................470

III. EXISTING CIVIL LIABILITY PROTECTIONS ..............................................473

A. Federal Law …………………………………………......476

1. Public Readiness and Emergency Preparedness Act

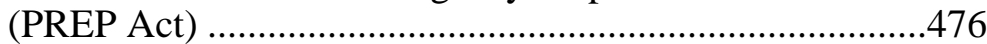

2. Volunteer Protection Act of 1997 (VPA) .............................477

B. New York State Law ……………………………………….......47

1. The Disaster Act .....................................................................479

2. New York State Good Samaritan Laws...............................480

3. New York Public Officers Law $§ 17$....................................481

4. New York State Law Offers Inadequate Liability

Protections …………………………………………........ 482

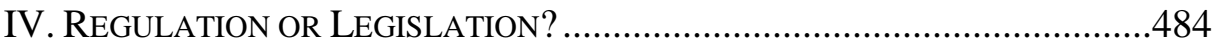

V. UNIQUE APPROACHES TO MITIGATING CIVIL LIABILITY ...........................487

A. Immunity-Conferring Legislation ...............................................487

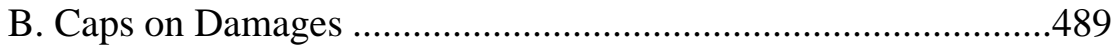

C. Expedited Discovery and Statutes of Limitations........................490

D. Alternative Resolution Procedures .............................................491

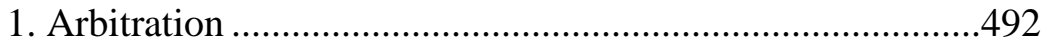

2. Pretrial Review Panels..........................................................494

3. Compensation Pools ............................................................495

E. Judge, Court, and Attorney Education ..........................................497

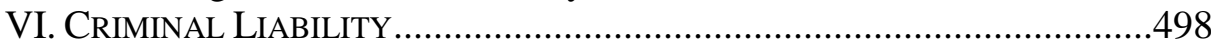

VII. CONCLUSION AND PROPOSALS FOR LEGISLATION ………………….......500

\footnotetext{
* Valerie Gutmann Koch, J.D., is a Visiting Assistant Professor at Chicago-Kent College of Law and Consultant to the New York State Task Force on Life and the Law; she is the former Senior Attorney to the Task Force.

${ }^{* *}$ Beth E. Roxland, J.D., M. Bioethics is a Visiting Scholar at Hofstra University; she is the former Executive Director of the Task Force on Life and the Law.

Both authors wish to express their gratitude to Carrie Zoubul, J.D., M.A., Andrew Cohen, and Phoebe Stone, J.D. for their assistance on this article. In addition, thank you to Susie Han, M.A., M.A., Robert Swidler, J.D., and Donald P. Berens, Jr., J.D. for their thoughtful review and comment. The statements, opinions, and interpretations contained in this article are the authors' own and do not represent the views or positions of the New York State Department of Health, Health Research, Inc. or the Task Force.
} 


\section{INTRODUCTION}

In a severe influenza pandemic, many more patients would require the use of mechanical ventilators than can be accommodated with current supplies. While federal and state ventilator stockpiles exist and New York state plans to buy additional ventilators that would meet the needs of patients in a moderately severe pandemic, ${ }^{1}$ existing stockpiles would be inadequate to meet the needs of a disaster on the scale of the 1918 influenza pandemic. $^{2}$ Even if the vast number of ventilators needed for a disaster of that scale were purchased, the requisite amount of trained healthy staff and other resources, such as oxygen, may not be available due to the nature of the emergency. Consequently, New York State and the rest of the country must proactively confront the rationing of resources in preparation for the possibility of severe ventilator scarcity in an influenza pandemic.

In March 2007, a working group convened by the New York State Task Force on Life and the Law (Task Force) and the New York State Department of Health released a draft guidance document entitled Allocation of Ventilators in an Influenza Pandemic (Ventilator Guidelines or Guidelines). ${ }^{3}$ The non-binding Guidelines contain a comprehensive clinical and ethical framework to guide distribution of ventilators in the event of a severe public health emergency using objective medical criteria, with the ultimate goal of saving the most lives. This document was among the first in the nation to confront this very sensitive and difficult topic, ${ }^{4}$ and other states have subsequently developed similar allocation plans. ${ }^{5}$

1. New York State Department of Health, Allocation of Ventilators in an Influenza Pandemic, Draft for Public Comment, $1, \quad 11 \quad$ (March 15, 2007), available at http://www.health.state.ny.us/diseases/communicable/influenza/pandemic/ventilators/docs/ventilator_guida nce.pdf (hereinafter "Ventilator Guidelines"). The recommendations included requirements that clinical evaluation be based upon universally applied objective criteria and that patients be equally subject to triage guidelines, regardless of their disease category or role in the community. The Ventilator Guidelines also stressed the need for state-wide consistency to prevent inequalities between care facilities, the development of legal protections for providers who comply with the guidelines, and the availability of palliative care.).

2. See The Great Pandemic, U.S. DeP'T OF HEAlth AND Human SERvs., at www.flu.gov/pandemic/history/1918/the_pandemic/index.html (last visited February 5, 2013) (citing global mortality estimates between thirty and fifty million, and American mortality estimates at 675,000).

3. See Ventilator Guidelines, supra note 1. At the time of publication, the Task Force was undertaking an examination of contemporary ethical issues and clinical data, in order to release the second edition of the guidelines. See New York State Department of Health, Task Force on Life \& the Law Current Projects, at http://www.health.ny.gov/regulations/task_force/current_projects/ (last visited Jan. 9, 2012). The considerations discussed in this article will form the basis of the legal section of the revised guidelines.

4. Tia Powell et al., Allocation of Ventilators in a Public Health Disaster, 2 Disaster Med. \& PuB. HEALTH PREPAREDNESS 20, 20 (2008).

5. See, e.g., Florida Department of Health, Pandemic Influenza: Triage and Scarce Resource Allocation Guidelines (Draft) (Apr. 5, 2011), available at http://www.doh.state.fl.us/demo/bpr/PDFs/ACS-GUIDEVer10-5.pdf; Dorothy E. Vawter et al., For the Good of Us All: Ethically Rationing Health Resources in Minnesota in a Severe Influenza Pandemic (2010), available at 
Notably, and by necessity, the Guidelines represent a significant departure from standard medical practice. In a non-crisis setting, the prevailing medical standard of care focuses on the needs of each individual patient and is centered on the principle of informed consent. In a public health emergency, however, such concentrated care may be impossible or inadvisable due to: (1) resource limitations and (2) the goal of saving as many lives as possible. The Guidelines acknowledge that health care providers may be hesitant to conform to the crisis medical standard of care contained therein due to concerns about liability arising from injury or death. ${ }^{6}$ Adhering to the Guidelines - despite their significant public health goals - may expose health care providers and entities to considerable costs and burdens, including the risk of jail time and/or financial penalties, the time and costs of discovery and preparing a case, higher medical malpractice insurance rates, and damage to one's reputation, unless proper and adequate legal protections are in place.

This article addresses the issue of liability for health care workers and entities who adhere to the recommended clinical protocol contained in the Ventilator Guidelines while rendering care in a disaster emergency, which has been characterized as one of the "most challenging legal questions related to the pandemic." After considering in Section II of the "trigger" for implementing emergency plans - a declaration of a public health or disaster emergency - Section III explores current federal and state law that might offer immunity, defense, or indemnification to certain individuals or entities who provide care in response to that declaration. The article then turns in Section IV to a consideration of several unique alternative approaches to mitigate clinicians' and other entities' burdens in the event of a civil lawsuit. Section V addresses issues of potential criminal liability

http://www.health.state.mn.us/divs/idepc/ethics/ethics.pdf; Utah Department of Health, Utah Pandemic Influenza Plan (2007), available at http://pandemicflu.utah.gov/plan/CorePanFlu-10012007.pdf. See also Gianfranco Pezzino, Guide for Planning the Use of Scarce Resources During a Public Health Emergency in Kansas, at 10 (Sept. 2009), available at http://www.kdheks.gov/cphp/download/

GuideforPlanningUseofScarceResources.pdf.

6. This may be of particular concern where they recommend ventilator withdrawal without patient consent. Some commentators have asserted that there may be a legal distinction between withholding and withdrawing life-sustaining treatments or therapies (such as ventilators), and have noted the potential for increased liability concerns with the latter. See Philip D. Levin \& Charles L. Sprung, Withdrawing and Withholding Life-Sustaining Therapies are Not the Same, 9 CRITICAL CARE 230 (2005); Ventilator Guidelines, supra note 1. But see American Medical Association, Opinion 2.20 - Withholding or Withdrawing LifeSustaining Medical Treatment, at http://www.ama-assn.org/ama/pub/physician-resources/medicalethics/code-medical-ethics/opinion220.page (last visited Feb. 1, 2012) ("There is no ethical distinction between withdrawing and withholding life-sustaining treatment.”); Asha Devereaux et al., Summary of Suggestions from the Task Force for Mass Critical Care Summit, January 26-27, 2007, 133 CHEST 1S, 6S (2008) ("Rationing should apply equally to withholding and withdrawing life-sustaining treatments based on the principle that withholding and withdrawing care are ethically equivalent").

7. Ventilator Guidelines, supra note 1, at 3 . 
and Section VI culminates in recommendations for legislation granting adequate civil and criminal liability protections to health care workers and entities who adhere to the state's Ventilator Guidelines in a pandemic.

Although this article focuses on New York State law and policy, just as the Ventilator Guidelines served as the basis for other states' scarce resource allocation plans, the issues considered here are applicable in other jurisdictions - just as the clinical and ethical guidance in the Ventilator Guidelines themselves - in order to encourage appropriate behavior in a severe pandemic event.

\section{EMERGENCY DECLARATIONS AND EXECUTIVE ORDERS}

A governmental declaration of a disaster or public health emergency might both signal the applicability of emergency plans and guidelines and make available some liability protections for certain health care workers and entities who provide care during the emergency. ${ }^{8}$ At the federal level, the President of the United States can declare a federal state of emergency or major disaster in accordance with the Robert T. Stafford Disaster Relief and Emergency Assistance Act ("the Stafford Act") 9 or the National Emergencies Act. ${ }^{10}$ The Secretary of Health and Human Services ("HHS") may also declare a public health emergency in the case of disease, disorder, or bioterrorist attack. ${ }^{11}$

In addition, every state has a procedure for declaring a state of emergency, disaster, or crisis. ${ }^{12}$ In New York State, the Governor has the authority, pursuant to Article 2-B of the New York State Executive Law ("the Disaster Act"), ${ }^{13}$ to declare a state of emergency whenever "a disaster has occurred or may be imminent for which local governments are unable to respond adequately." 14 The Disaster Act confers certain response duties

8. Emergency declarations may also trigger the availability of resources, such as stockpiles, that are only available in emergencies.

9. Federal Emergency Management Act, 42 U.S.C. $\$ \$ 5121-5208$ (2000).

10. Declaration of National Emergency by President, 50 U.S.C. $§ 1621$ (2000). President Bush declared an emergency under the National Emergencies Act after the September 11, 2001 attacks.

11. Public Health Service Act, 42 U.S.C. $§ 247 d$ (2011). The Secretary declared public heath emergencies in reaction to the September 11 attacks and Hurricane Katrina.

12. In addition to general emergency procedures, some states have protocols for public health emergencies, which trigger various additional powers, including changing the functions of state governmental agencies. New York does not have a public health emergency statute delineated as such, nor is "public health emergency" defined in New York law or administrative regulations. Enacting such a statute might clarify the authority of the Governor and/or Health Commissioner in declaring a crisis medical standard of care or modified immunity standards for health care workers who provide care during an emergency.

13. N.Y. EXEC. LAW $\$ 20$ (McKinney 2012).

14. N.Y. EXEC. LAW § 28(1) (McKinney 2012) (the New York State and Local Natural Disaster and ManMade Disaster Act). 
and obligations on the state in a declared emergency ${ }^{15}$ and includes broad powers to cope with such a crisis. Notably, although the Department of Health has authority over the institutional aspects of medical care and is empowered to issue binding regulations for hospitals that would apply to standards of care, it generally does not have the power to regulate the private practice of medicine. ${ }^{16}$

The Disaster Act describes the power to issue executive orders, or rules to be followed during the pendency of the emergency; ${ }^{17}$ the governor "may by executive order temporarily suspend specific provisions of any statute, local law, ordinance, or orders, rules or regulations, or parts thereof, of any agency during a state disaster emergency, if compliance with such provisions would prevent, hinder, or delay action necessary to cope with the disaster." 18 Any suspension of civil or criminal law is valid for thirty days, with an additional possible extension of thirty days. ${ }^{19}$

The ability to suspend relevant laws pursuant to the Disaster Act, however, is limited. First, the Governor may not suspend a law that safeguards public health and welfare that is not "reasonably necessary" to the

15. N.Y. EXEC. LAW $§ 22(3)(b)$ (McKinney 2012). For example, the Act lays out a number of response plans to be implemented by the state, including ("but not limited to"), "plans for the continued effective operation of the civil and criminal justice systems" and "utilization and coordination of programs to assist victims of disasters...."

16. For example, under New York law, in hospitals and other health care facilities subject to Public Health Law Article 28, the Commissioner of Health has some discretionary power to regulate aspects of medical practice. N.Y. PUB. HEALTH LAW $\S 2803$ (McKinney 2012). Where a proposed regulation would relate to the private practice of medicine, however, the Education Law would seem to forbid its promulgation, even in an emergency. N.Y. EDUC. LAW $\$ 6532$ prohibits the Department of Health (as well as the Department of Education) from promulgating rules or regulations concerning the practice of physicians who are licensed and authorized to practice their profession under the state's Education Law. N.Y. EDUC. LAW $\S \S$ 6520-6529 (McKinney 2012). Even if the Department of Health could promulgate new rules or regulations, it would not have the authority to enforce such regulations unless the Education Law was also amended to include violation of that regulation in its grounds for professional misconduct. N.Y. EDUC. LAW § 6530 (McKinney 2012). For example, when the law governing office-based surgery ("OBS”) was passed, which required the accreditation of OBS and established requirements for reporting adverse events, the Education Law also had to be amended to add a new ground for professional misconduct for violation of N.Y. PUB. HEALTH LAW § 230-d (McKinney 2012).

17. Similarly, in Colorado, a list of draft executive orders has been drafted to be signed and used by the Governor in the event of a public health emergency. The Governor's Expert Emergency Epidemic Response Committee ("GEEERC") was statutorily created in 2000 to develop a public health response to "acts of bioterrorism, pandemic influenza and epidemics caused by novel and highly fatal infectious agents." See Colo. Rev. Stat. § 24-32-2104(8) (2010). For a list of the state's draft executive orders, see Colorado Department of Public Health \& Environment, Governor's Expert Emergency Epidemic Response Committee Draft Executive Orders (Apr. 26, 2006), available at http://www.cdphe.state.co.us/epr/Public/InternalResponsePlan/Attachment3.pdf.

18. N.Y. EXEC. LAW § 29-a (McKinney 2012). There are a number of instances where the New York State governor has suspended statutes during declared emergency. For example, in the aftermath of September 11, Governor Pataki temporarily suspended and modified statutory provisions related to the mandatory retirement of members of the state police. N.Y. Comp. Code R. \& Regs. Tit. 9, § 5.113.36-A (Oct. 16, 2001). Governor Pataki also suspended the speedy trial deadlines of Criminal Procedure Law $§ 30.30$.

19. N.Y. EXEC. LAW § 29-a(2)(a) (McKinney 2012). 
disaster effort. ${ }^{20}$ Second, the Disaster Act does not allow suspension of rights granted by the federal or state constitutions, ${ }^{21}$ such as those related to due process, equal protection, or governmental takings. ${ }^{22}$ Third, most civil (including much of the law regarding informed consent, physicianpatient relationships, and medical malpractice) and some criminal liabilities are not detailed by statute but are the product of common law (i.e., case law and precedent), and therefore may not be suspended by the governor pursuant to the Disaster Act. ${ }^{23}$

In contrast to statutes, agency regulations and guidelines can be suspended without invocation of the governor's emergency powers. ${ }^{24}$ An agency may also adopt a temporary emergency rule without normal notice and comment procedures. ${ }^{25}$ An agency may not promulgate a rule under the emergency power if it could not promulgate that same rule under normal rule-making procedures, and a notice of emergency adoption mustcite the statutory authority under which the rule is adopted. ${ }^{26}$ Emergency rules

20. In re World Trade Ctr. Disaster Site Litig., 456 F. Supp. 2d 520 (S.D.N.Y. 2006); N.Y. EXEC. LAW § 29-a(2)(b) (McKinney 2012).

21. See, e.g., DeBari v. Town of Middleton, 9 F. Supp. 2d 156, 160 (N.D.N.Y. 1998).

22. One of the takings issues associated with the guidelines includes the authority to appropriate privately owned (by individuals with a chronic disease or by private hospitals) ventilators. See Joint Meeting of the Ethics Subcommittee of the Advisory Committee to the Director, Centers for Disease Control and Prevention (CDC), and CDC's Public Health Ethics Committee, Minutes, at 2 (October 15, 2009).

23. Significant attention must be paid to any governor's orders arising from a declaration of disaster emergency, particularly those related to when a lawsuit is commenced, tried, or resolved after the expiration of the suspensions order. After the September 11 terrorist attacks, Governor Pataki declared a disaster emergency and implemented various forms of relief, including suspending a criminal law that requires the government to announce their readiness for trial within six months of the commencement of a felony action. N.Y. COMP. CODE R. \& REGS. Tit. 9, § 5.113 .7 (2001). Under the Executive Orders, the time period allotted to the People to announce they were ready for trial (i.e., 90 days for a class A misdemeanor) did not include any excludable time. After September 11, many suits arose disputing the contours of the suspension, particularly regarding how the speedy trial time should be calculated. People v. Forbes, 745 N.Y.S.2d 414 (2002); People v. Wright, 748 N.Y.S.2d 199 (2002). It was clear from the Executive Orders that, if the limitation period ended during the pendency of the Executive Orders, the case would not be dismissed pursuant to CPL $\S 30.30$. People v. Pena, 2002 NY Slip Op. 40129U, 10-11, 2002 N.Y. Misc. LEXIS 394 (2002). The court held that in cases in which the Orders did not clarify the effect of the final day of the speedy trial time falling after the time frame established therein, that the Orders require some analysis as to whether a delay requested by the People might constitute a delay due to "exceptional circumstances" because it related to the World Trade Center emergency.

24. New York's Administrative Procedure Act provides for emergency adoption of rules by an agency if it "is necessary for the preservation of the public health, safety or general welfare," where there is appropriate statutory authority for such an adoption. N.Y. A.P.A. § 202(6) (McKinney 2012). Thus, the Department of Health could, among other things, suspend its own regulations.

25. Id. (" $[\mathrm{I}] \mathrm{f}$ an agency finds that the immediate adoption of a rule is necessary for the preservation of the public health, safety or general welfare and that compliance with the requirements of subdivision one of this section [describing the normal notice and comment requirements for rule making] would be contrary to the public interest, the agency may dispense with all or part of such requirements and adopt the rule on an emergency basis.").

26. Id. $\$ 202(6)(\mathrm{d})(\mathrm{i})$. 
are in effect for ninety days,${ }^{27}$ but may be readopted on an emergency basis. $^{28}$

In planning for a pandemic, it may be useful to identify statutes, ${ }^{29}$ regulations, and guidelines ${ }^{30}$ that might be suspended in an influenza pandemic, which may conflict with effectively implementing the Ventilator Guidelines. ${ }^{31}$

\section{EXISTING CIVIL LIABILITY PROTECTIONS}

In adhering to guidelines recommending modified behavior during an emergency, both individuals and entities face potential liability under a number of civil and criminal theories. Civil claims could encompass liability for negligence, professional malpractice, breach of contract, breach

27. $I d . \S 202(6)(\mathrm{b})$.

28. Id. $\S 202(6)(\mathrm{e})$.

29. The following is a non-exclusive compilation of some of the state statutes that might be waived in order to effectively implement the Guidelines: N.Y. Pub. HEALTh LAW $§ 2801-d$ ("Private Actions by Patients of Residential Health Care Facilities"); N.Y. Pub. HEaLTh Law § 2803-c ("Rights of Patients in Certain Medical Facilities"); N.Y. Pub. Health LaW § 2805-b(2)(a); N.Y. Pub. HeAlth LaW Art. 29-B ("Orders Not to Resuscitate for Residents of Mental Hygiene Facilities"); N.Y. PUB. Health LaW 29-C ("Health Care Agents and Proxies"); N.Y. Pub. Health Law Art. 29-CC ("Family Health Care Decisions Act"); N.Y. Pub. Health LaW Art. 29-CCC ("Nonhospital Orders Not to Resuscitate"); N.Y. EduC. LaW $\S 6530$ ("Definitions of Professional Misconduct"). As noted above, the State Education Department regulates the "professional conduct" for licensed health care workers, while the Department regulates hospitals. N.Y. EDUC. LAW § 6504. Article 131-A of the State Education Law governs the professional misconduct in the practice of medicine. A suspension of the laws governing negligent practice might ease the pressure on health care workers who provide care pursuant to the Ventilator Guidelines. N.Y. EDUC. LAW $§ 6530$ defines professional misconduct of physicians, physician's assistants, and specialist's assistants, as (among other definitions) "[p]racticing the profession with negligence on more than one occasion." N.Y. EDUC. LAW $\S 6509$ defines professional misconduct for other professions, as (among other things) "negligence or incompetence on more than one occasion." However, the law allows charges to "be dismissed in the interest of justice," thereby potentially rendering suspension of the law unnecessary. It is also possible that a declaration of a state of emergency may allow the governor to modify or suspend New York Civil Practice Law and Rules (C.P.L.R.) - particularly as they apply to discovery - in order to ameliorate the burden on health care workers who adhere to the Guidelines. However, this proposal is problematic on a number of levels. First, it might be challenging to fit suspension of civil discovery rules into the Disaster Act's requirement that "[n]o suspension shall be made which does not safeguard the health and welfare of the public and which is not reasonably necessary to the disaster effort," because there is little to no instructive case law on what constitutes "reasonably necessary." N.Y. EXEC. LAW § 24(1)(g)(2)(ii). Second, the effects of such an order would be subject to the Act's requirement that no suspension be made for a period in excess of thirty days, and - even if extended - would only be in effect during the duration of the declared state of emergency.

30. Guidelines, like those in the draft 2007 report, differ from regulations, which are binding rules or standards promulgated by government agencies (like the New York State Department of Health). Under New York law, a regulation is "a fixed, general principle to be applied by an administrative agency without regard to other facts and circumstances relevant to the regulatory scheme of the statute it administers." In re Suffolk Regional Off-Track Betting Corp. v. N.Y. State Racing \& Wagering Board, 872 N.Y.S.2d 419 (2008); In re Roman Catholic Diocese of Albany v. N.Y. State Dep't of Health, 66 N.Y.2d 948 (1985). Laws, on the other hand, are created by statutes that originate from legislative bills in the state or federal legislature.

31. Ventilator Guidelines, supra note 1, at 39-40. 
of fiduciary duty, intentional infliction of emotional distress, or other intentional torts (including battery). ${ }^{32}$

The elements of a negligence claim (the most likely of these civil claims) are: (1) a duty of care owed by the defendant to the plaintiff, (2) breach of that duty, (3) harm or injury to the plaintiff, and (4) a causal link between the injury and the breach of duty. ${ }^{33}$ The defendant's duty to the plaintiff is defined by the legal standard of care. For personal negligence claims - particularly those based in medical malpractice - against individual physicians, New York courts apply the "prudent doctor standard," requiring that the physician exercise due care, "as measured against the conduct of his or her own peers." 34 The state generally applies the "same community" standard to this determination, wherein the state's case law specifies that practice in the local community determines the standard of care. ${ }^{35}$

Moreover, health care providers may be alleged to have committed gross negligence under a crisis standard of care that arises in a pandemic. Under New York law, gross negligence is more than just an egregious form of negligence and can more appropriately be defined as willful misconduct or intentional wrongdoing. Gross negligence differs "in kind, not only degree, from claims of ordinary negligence" and is "conduct that evinces a reckless disregard for the rights of others or 'smacks' of intentional wrongdoing." ${ }^{36}$

With respect to entities - including hospitals, clinics, and health care organizations - claims are likely to sound in corporate negligence and vi-

32. Except where a federal cause of action is established by statute, medical malpractice claims are governed by state common law. The State's informed consent doctrine is premised on battery. Schloendorff v. Soc'y of N.Y. Hosp., 211 N.Y. 126 (1914) ("Every human being of adult years and sound mind has a right to determine what shall be done with his own body; and a surgeon who performs an operation without his patient's consent commits an assault for which he is liable in damages.").

33. Sharona Hoffman, Responders' Responsibility: Liability and Immunity in Public Health Emergencies, 96 GEO. L.J. 1913, 1926 (2008).

34. McCullough v. Univ. Rochester Strong Mem. Hosp., 794 N.Y.S.2d 237 (2005); Nestorowich v. Ricotta, 97 N.Y.2d 398 (2002); Caristo v. Sanzone, 96 N.Y.2d 174 (2001) (applying the common-law emergency doctrine, whereby an individual faced with "a sudden and unexpected circumstance which leaves little or no time for thought, deliberation or consideration" is judged on whether the response is that of a reasonably prudent person under the circumstances).

35. In some cases, courts have deviated from applying the locality rule and instead sometimes apply a minimum statewide standard of care or even a nationwide standard. For further discussion, see Michelle Huckaby Lewis et al., The Locality Rule and the Physician's Dilemma: Local Medical Practices vs. The National Standard of Care, 297 JAMA 2633 (2007).

36. Colnaghi, USA Ltd. v. Jewelers Protection Servs., Ltd., 81 N.Y.2d 821 (1993). Contractual releases from gross negligence are likely not enforceable in New York in any event. David Shine, Contractual Applications of Negligence/Gross Negligence Standards: Considerations Under New York Law, THE M\&A LAWYER (2005), available http://www.friedfrank.com/siteFiles/Publications/056EFA672B52519D1926370EFAF84809.pdf. 
carious liability. ${ }^{37}$ A corporate negligence theory requires a showing of: (1) a duty of care; (2) a breach of that duty by deviating from the standard of care; (3) actual or constructive notice of the defects or procedures that caused the harm; and (4) a causal link between the conduct and harm. ${ }^{38}$ The entity's duty of care includes maintaining safe and adequate facilities, hiring only competent physicians, overseeing all persons who practice medicine under its auspices, and formulating and enforcing appropriate rules and policies to ensure quality care for patients. A vicarious liability claim may arise against a hospital or other health care entity for the acts of an independent physician where the physician was provided by the hospital or was otherwise acting on the hospital's behalf, and the patient reasonably believed that the physician was acting at the hospital's behest. ${ }^{39}$

At both the state and federal level, no uniform legal protection exists for the provision of care pursuant to disaster plans or guidance during a health crisis. For example, although current laws offer some legal safeguards for health care workers and entities, they vary according to the population they cover. Many apply only to unpaid volunteers, ${ }^{40}$ while fewer offer protections for compensated health care providers. At best, they provide immunity from a finding of liability. Likewise, the various laws provide different levels of protection: some laws provide civil liability immunity while others indemnify providers. Notably, no federal or New York State law provides immunity from suit altogether. Further, the majority of applicable laws protect providers conditionally (e.g., if the defendant has not engaged in willful or intentional misconduct or gross negligence), rather than offering unconditional protections against liability.

37. Vicarious liability refers to the responsibility of superiors for the acts of subordinates, and is particularly applicable in the hospital context.

38. Hoffman, supra note 33, at 1918 (discussing Elam v. Coll. Park Hosp., 183 Cal. Rptr. 156 (Ct. App. 1982) (hospital held liable under the doctrine of corporate negligence where independent contractors negligently performed pediatric surgery at the hospital); Insinga v. Labella, 543 So. 2d 209, 214 (Fla. 1989) (recognizing the corporate negligence doctrine as the independent duty the hospital owes to patients, and finding that because the hospital is in "a superior position to supervise and monitor physician performance," it is "the only entity that can realistically provide quality control."); Darling v. Charleston Cmty. Mem'l Hosp., 211 N.E.2d 253, 257 (Ill. 1965); Oehler v. Humana, Inc., 775 P.2d 1271, 1272 (Nev. 1989) (hospital and governing board may be liable for failure to supervise treatment by non-employed physicians under corporate negligence theory of liability); Pedroza v. Bryant, 677 P.2d 166 (Wash. 1984) (expressly adopting corporate negligence theory)).

39. Sarivola v. Brookdale Hosp. \& Med. Ctr., 612 N.Y.S.2d 151, 152 (App. Div. 1st Dep't 1994); Soltis v. State, 568 N.Y.S.2d 470 (App. Div. 3d Dep't 1991).

40. Broadly, volunteers are health care workers from unaffected areas who may provide assistance in a place of emergency, or retirees or students with medical training who volunteer their services during a declared disaster emergency. "Spontaneous" untrained volunteers are less of a concern in cases concerning ventilator allocation in a flu pandemic than in dealing with other public health emergencies, and will therefore not be addressed here. See Hoffman, supra note 33, at 1957-58. 


\section{A. Federal Law}

Two primary pieces of legislation offer some liability protections to health care workers and entities that provide care during a public health emergency: the Public Readiness and Emergency Preparedness ("PREP") Act and the Volunteer Protection Act of 1997 ("VPA").

\section{Public Readiness and Emergency Preparedness Act (PREP Act)}

Enacted in 2005, the PREP Act limits tort liability under state and federal law with respect to the use of "covered countermeasures" for pandemic flu or other public health threats. ${ }^{41}$ Specifically, upon a determination by the Secretary of HHS that either a public health emergency or the credible risk of such emergency exists, the Secretary may issue a declaration that certain "covered persons" are immune from liability with respect to claims arising from the administration or use of a covered countermeasure. ${ }^{42}$ Covered persons will not be held liable unless a "death or serious physical injury" was caused by "willful misconduct." include manufacturers, distributors, and program planners of countermeasures (i.e., individuals and entities involved in planning and administering programs for distribution of a countermeasure), as well as qualified persons who prescribe, administer, or dispense countermeasures (i.e., health care and other providers); and theUnited States. To the extent that lifesustaining equipment, such as mechanical ventilators, meets the criteria to be considered covered countermeasures, their appropriate use could qualify a provider for immunity from liability, so long as the providers' activities are part of a response plan and fall within the purview of a declaration by the Secretary of HHS in effect at the time. ${ }^{44}$

41. Targeted Liability Protections for Pandemic and Epidemic Products and Security Countermeasures, 42 U.S.C. § 247d-6d (2005)

42. Id.

43. Under the PREP Act, "willful misconduct" is defined as an act or omission that is taken "(i) intentionally to achieve a wrongful purpose; (ii) knowingly without legal or factual justification; and (iii) in disregard of a known or obvious risk that is so great as to make it highly probable that the harm will outweigh the benefit." Public Readiness \& Emergency Preparedness Act, 42 U.S.C. § 247d-6d(c)(1)(A) (2005). The Secretary of HHS, in consultation with the Attorney General, "shall promulgate regulations . . . that further restrict the scope of actions or omissions by a covered person that may qualify as "willful misconduct." 42 U.S.C. $§ 247 d-6 d(c)(2)(A)(2005)$. Furthermore, "the plaintiff shall have the burden of proving by clear and convincing evidence willful misconduct by each covered person sued and that such willful misconduct caused death or serious physical injury." 42 U.S.C. $§ 247 \mathrm{~d}-6 \mathrm{~d}(\mathrm{c})(3)$ (2005). The "clear and convincing" standard is higher than the proof by a "preponderance of the evidence" standard, the usual burden of proof in civil cases.

44. 42 U.S.C. $§ 247 d-6 d(i)(1)$ (2005). However, the wording of the PREP Act declaration "suggests that liability extends to federal contracts, etc. and activities authorized in response to a public health emergency; requirement of both elements would limit liability to only federal programs and not extend to state programs." CDC Public Health Law Program, After-Action Report: Legal Issues and the H1N1 Influenza 
However, the scope of the PREP Act is ambiguous. ${ }^{45}$ As an initial matter, although there is a strong argument that the establishment of a triage protocol for ventilators in a pandemic qualifies as a program for "the administration, dispensing, distribution, provision, or use of a security countermeasure or a qualified pandemic or epidemic product," it remains unclear whether a ventilator would qualify as a covered countermeasure. ${ }^{46}$ The PREP Act appears to be designed to insulate manufacturers and entities in the production, supply, and delivery of faulty countermeasures, such as an ineffective or contaminated anti-viral medication, which may have been rushed to market because of a public health emergency. ${ }^{47}$ Attempting to apply the PREP Act protections to allocation of a fully-functioning countermeasure such as ventilators is not guaranteed. Additionally, the statutory language of the PREP Act immunizes against affirmative administration of relevant measures; it is unclear whether it would apply equally to inaction regarding such measures. More specifically, the PREP Act protections may not extend to the withholding of a ventilator or other countermeasures pursuant to a state's emergency response plan. ${ }^{48}$

Accordingly, unless and until the Secretary of HHS approves for PREP Act protection of a plan by New York or another state that includes not only affirmative usage of ventilators, but also withholding or withdrawal of ventilator support, it may be unwise to rely on the PREP Act for full liability protection to ensure compliance with the Guidelines.

\section{Volunteer Protection Act of 1997 (VPA)}

The VPA provides immunity against liability for tort claims to volunteers who do not receive compensation in excess of $\$ 500$ per year and who serve governmental entities and nonprofit organizations. ${ }^{49}$ However, as with most immunity-conferring laws, the VPA does not cover harm caused by willful or criminal misconduct, gross negligence, reckless misconduct,

Pandemic, National Association of County \& City Health Officials, at 13 (Apr. 30, 2010), at http://www.naccho.org/topics/H1N1/upload/043010-H1N1-Legal-Issues-After-Action-Report.pdf.

45. Notably, because the PREP Act has been untested in court, the full extent of its protections is unclear. 46. 42 U.S.C. $§ 247 d-6 d(i)(6)(2005)$.

47. See, e.g., Eva B. Stensvad, Note, Immunity for Vaccine Manufacturers: The Vaccine Act and Preemption of Design Defect Claims, 95 MinN. L. REV. 315, 335 (2011).

48. After-Action Report: Legal Issues and the H1N1 Influenza Pandemic, supra note 44, at 13. Further, if the countermeasure (or withholding of the countermeasure) is mandated by the state, the PREP Act may not apply. See id. ("PREP Act coverage requires that the countermeasures be voluntary; would coverage still be extended should a state mandate that all healthcare workers, for example, be vaccinated").

49. Volunteer Protection Act, 42 U.S.C. $§ \S 14501-14505$ (1997). Government entities are generally understood to be the United States or any state, the District of Columbia, a U.S. possession (including Puerto Rico), a political subdivision of a state or U.S. possession, or an Indian tribal government or any of its subdivisions that perform substantial government functions. 
or a conscious, flagrant indifference to the rights or safety of the individual harmed by the volunteer. ${ }^{50}$ The VPA also includes a list of exceptions to the Act's liability limitations, including for crimes of violence or acts of international terrorism, hate crimes, sexual offenses, or violations of federal or state civil rights law. ${ }^{51}$ For the VPA's immunity protections to apply, a volunteer must be properly licensed, certified, or authorized by the appropriate state authorities, and the volunteer's activities must be undertaken within the scope of his or her responsibilities. ${ }^{52}$ The Act preempts any inconsistent state law, but does not preempt state law that provides additional protection from liability for volunteers. ${ }^{53}$ Notably, the VPA's protections do not depend on a declaration of emergency.

The VPA's liability limitations do not apply to nonprofit organizations or governmental entities that may be held vicariously liable for the ordinary negligence of their volunteers, even if volunteers themselves are immune. $^{54}$ Moreover, the Act explicitly permits nonprofit organizations or government entities to bring a civil action against the volunteer. ${ }^{55}$ Thus, it is entirely possible that an injured person could sue the entity responsible for the volunteer's involvement (under, for example, a vicarious liability theory), and the entity could then, in turn, sue the volunteer to recover the damages it had paid to the victim. Thus, the VPA's immunity provisions do not provide wholesale liability protections to those who provide care in a pandemic and almost certainly does not provide protections for frontline providers, such as hospitalists, for whom the Guidelines are aimed.

\section{B. New York State Law}

The Disaster Act, Good Samaritan Laws, and Public Officers Law offer protections - albeit incomplete ones - for health care workers and entities in a pandemic. ${ }^{56}$

50. 42 U.S.C. $\S 14503(a)(3)$.

51. 42 U.S.C. $\$ 14503(f)$.

52. 42 U.S.C. $\$ 14505$.

53. 42 U.S.C. $\$ 14502$.

54. 42 U.S.C. $\S \S 14503$ (c) ("No Effect on Liability of Organization or Entity. - Nothing in this section shall be construed to affect the liability of any nonprofit organization or governmental entity with respect to harm caused to any person").

55. 42 U.S.C. § 14503(b) (1997) (“Concerning Responsibility of Volunteers to Organizations and Entities. - Nothing in this section shall be construed to affect any civil action brought by any nonprofit organization or any governmental entity against any volunteer of such organization or entity.").

56. In addition, the New York State Defense Emergency Act ("SDEA"), provides a grant of immunity for civil defense workers for actions taken "in good faith carrying out, complying with or attempting to comply with any law, any rule, regulation or order duly promulgated or issued pursuant to" the SDEA and "relating to civil defense, including but not limited to activities pursuant thereto, in preparation for anticipated attack, during attack, or following attack or false warning thereof, or in connection with an authorized drill or test.” 
Importantly, because issues of malpractice and other liability are not detailed bystate statute, ${ }^{57}$ the state may not be able to provide additional liability protectionto health care providers based on the declaration of an emergency by order alone. ${ }^{58}$ Moreover, no state action would insulate health care workers from liability for breaches of federal law. For example, state action could not protect health care workers from alleged HIPAA $^{59}$ or EMTALA ${ }^{60}$ violations. Liability under federal law can be waived only by a declaration of a national public health emergency by the President or the Secretary of HHS. ${ }^{61}$ Likewise, constitutional claims alleging violations of due process, equal protection, or takings law would not be addressed by an application of state law as a result of a state declaration of emergency.

\section{The Disaster Act}

In addition to permitting the governor to declare a state of emergency, New York's Disaster Act grants civil immunity to actions taken by certain individuals "for any claim based upon the exercise or performance or the failure to exercise or perform a discretionary function or duty on the part of any officer or employee in carrying out" the law. ${ }^{62}$ Courts have held that in enacting the statute, the legislature intended to grant only im-

N.Y. LAW $\S 113$ (CONSOL. 2012). The immunity provision also extends to government, partnerships, and corporations, as well as individuals. Although the governor may invoke the SDEA following an "attack," pandemics are considered relatively foreseeable and would probably not qualify under the SDEA. 2008 Pandemic Influenza Plan New York State Department of Health, Command and Control, New YORK STATE DEP'T OF HEALTH (2008), at http://www.health.state.ny.us/diseases/communicable/influenza/pandemic/plan/docs/section_1.pdf. In the New York Court of Appeals' only case addressing the SDEA's immunity provisions, the court noted that, "[1]iability is the rule, immunity the exception . . The rule of non-liability is out of tune with life about us, at variance with modern-day needs and with concepts of justice and fair dealing." Abbott v. Page Airways, Inc., 245 N.E.2d 388, 390 n. 2 (N.Y. 1969) (quoting Bing v. Thunig, 143 N.E.2d 3 (1957) (alterations in original)).

57. This excludes the Tort Claims Act for public employees and the Good Samaritan Acts. See N.Y. Ct. Claims Act $\S \S 8-12,15,20$-a, 26.

58. Donna Levin et al., Altered Standards of Care During an Influenza Pandemic: Identifying Ethical, Legal, and Practical Principles to Guide Decision Making, 3 (Supp. 2) DisASTER MED. \& PUB. HEALTH PREPAREDNESS S132, S133 http://www.dmphp.org/cgi/content/full/3/Supplement_2/S132.

59. HIPAA Privacy Rule, 45 C.F.R. $\$ 160$ et seq. The HIPAA Privacy Rule provides federal protections for personal health information held by covered entities and gives patients an array of rights with respect to that information.

60. Emergency Medical Treatment and Active Labor Act, 42 U.S.C $§ 1395 d d(a)$. EMTALA requires that hospital emergency rooms screen all patients who seek emergency treatment.

61. In order to waive HIPAA and EMTALA mandates, the President may issue emergency declarations allowing the HHS Secretary to act.

62. N.Y. EXEC. LAW § 25(5) (McKinney 2012). See also In re World Trade Ctr. Disaster Site Litig., 456 F. Supp. 2d 520, 558 (2d Cir. 2008). 
munity from liability - not immunity from suit. ${ }^{63}$ In other words, covered parties can still be sued and forced to go to court for civil liability allegations that arise out of care provided in a declared emergency, but the Disaster Act may prevent a finding of liability. Liability protections also would be unlikely to extend beyond political subdivisions and their employees and officers; at least one court has opined that "[h]ad the legislature intended for immunity to extend to private [compensated nongovernment] actors, it could easily have so provided." ${ }^{64}$ Recently, the Disaster Act's immunity provisions were modified to also apply to local "affiliated" volunteers acting within the scope of duties set forth in a Comprehensive Emergency Management Plan, to the extent that a formal "affiliation" has been established. ${ }^{65}$ It is unclear whether the Act would cover clinicians' conduct if their actions occurred within the normal scope of duties. Paradoxically, such clinicians would be the exact health care providers who would likely be sued for following the Guidelines.

\section{New York State Good Samaritan Laws}

Under New York's Good Samaritan laws, physicians, physician assistants, dentists, physical therapists, nurses, and podiatrists who provide care at the scene of an accident or emergency are immune from civil liability claims. ${ }^{66}$ However, such laws apply only to care provided outside a hospital, doctor's office, or other place having proper and necessary medical equipment. ${ }^{67}$ Moreover, the state's Good Samaritan laws apply to only voluntary and uncompensated individuals, and not to professionals acting in the context of their normal duties or with a pre-established duty of care to the patient. ${ }^{68}$ Consequently, Good Samaritan laws exclude a major por-

63. In re World Trade Ctr. Disaster Site Litig., 456 F. Supp. 2d at 558.

64. Id.

65. N.Y. EXEC. LAW $§ 20(2)($ g) (McKinney 2012) (defining "disaster emergency response personnel" under N.Y. EXEC. LAW $§ 29-b(1)$ as "agencies, public officers, employees, or affiliated volunteers having duties and responsibilities under or pursuant to a comprehensive emergency management plan.").

66. N.Y. Pub. Health LAW § 3000-a(1) (McKinney 2012); N.Y. EduC. LAW § 6527 (McKinney 2012) (applying non-liability to licensed physicians providing voluntary and uncompensated first aid or emergency treatment at the scene of an accident or other emergency outside a hospital, doctor's office, or any other place having proper and necessary medical equipment, to a person who is unconscious, ill, or injured), Id. at $\$ 6547$ (stating that a physician assistant rendering first aid or emergency treatment at the scene of an accident or outside a hospital or doctor's office is not liable for damages, injuries, or death unless it is established that the injuries or death are caused by gross negligence), $I d$. at $\$ 6737$ (applying non-liability for licensed physical therapists for first aid or emergency treatment), Id. at $§ 6909$ (applying non-liability for nurses for providing uncompensated first aid or emergency treatment), $I d$. at $\S 7006$ (applying non-liability for podiatrists for providing uncompensated first aid or emergency treatment), Id. at $\S 6611$.

67. Id.

68. Generally, volunteers are covered by Good Samaritan laws only if they are not compensated. Hoffman, supra note 33 , at 1952. 
tion of those health care professionals who provide care within a hospital setting and/or as part of their employment - the most likely caregivers in a disaster scenario. ${ }^{69}$ In addition, New York's Good Samaritan laws do not provide liability protections to entities such as hospitals and businesses or insulate health care providers from criminal liability. ${ }^{70}$

\section{New York Public Officers Law $§ 17$}

New York Public Officers Law Section 17 provides for both the defense and the indemnification of New York State "employees." "Employee" is somewhat broadly defined, and health care providers may be covered if they are "volunteer[s] expressly authorized to participate in a state-sponsored volunteer program." 71 New York Public Health Law Section 14 extends Section 17 to any physician, dentist, nurse, or other health care professional who "is licensed to practice pursuant to [New York State Education Law] and who is rendering professional treatment or consultation in connection with professional treatment authorized under such license at the request of the Department, or at a departmental facility."72

Under Section 17, the State's duty to defend is broader than its duty to indemnify. The law requires New York State to provide for the defense of its employees "in any civil action or proceeding in any state or federal court arising out of any alleged act or omission which occurred or is alleged in the complaint to have occurred while the employee was acting within the scope of his public employment or duties." "73 Further, the law

69. For a summary of states' Good Samaritan laws, see Department of Health \& Human Services, Emergency System for Advance Registration of Volunteer Health Professionals (ESAR-VHP) - Legal and Regulatory Issues, CENTERS FOR LAW \& THE PUBLIC'S HEALTH, 95 (May 2006), at http://www.publichealthlaw.net/Research/PDF/ESAR\%20VHP\%20Report.pdf.

70. Further, charitable immunity statutes offer an affirmative defense (even outside a state of emergency) to a liability action for organizations that derive its funds mainly from public and private charity. Fortythree states - not including New York - and the District of Columbia have enacted non-emergent charitable immunity legislation, thirty-six of which have legislatively changed the legal standard of care from negligence to gross negligence (or a "willful or wanton" or "reckless" standard). Paul A. Hattis \& Janet Walton, Volunteers in Health Care, Understanding Charitable Immunity Legislation (Nov. 2003), available at http://www.operationgivingback.facs.org/stuff/contentmgr/files/035c41f19a8dcf8a1e89b218e2d724fb/misc /vihcharit.imm.man.pdf.

71. N.Y. Pub. OfF. LaW § 17(1)(a) (McKinney 2012). See also New York State Dep't Health Office of Health Emergency Preparedness, Questions and Answers, available at http://www.health.state.ny.us/funding/rfa/1007161051/questions_and_answers.pdf. Among others, an employee can be "any person holding a position by election, appointment or employment in the service of the state ... whether or not compensated, or a volunteer expressly authorized to participate in a state-sponsored volunteer program, but shall not include an independent contractor." Health care providers employed by the state are covered if they are otherwise eligible. Persons employed by the Roswell Park Cancer Institute and engaged in clinical practice pursuant to a clinical practice plan established by the Commissioner of Health pursuant to N.Y. PUB. OFF. LAW § 206(14) are covered if they are otherwise eligible.

72. N.Y. Pub. HEALTH LAW § 14 (McKinney 2012).

73. N.Y. PUB. OFF. LAW § 17(2) (McKinney 2012). 
requires the state to provide indemnity to employees of public state entities acting within the scope of public employment or duties unless the damages "resulted from intentional wrongdoing." "74 If a judgment is entered against such an individual, the state must indemnify and hold harmless him or her in the amount of any judgment or settlement. In these cases, his or her primary malpractice insurance would be responsible to pay the judgment, and to the extent that one has no insurance or the insurance is exhausted, the State would cover the individual for the difference.

Amendment of Public Officers Law Section 17 to require the defense or indemnification of all health care providers in actions arising from their adherence to the Guidelines, whether or not employed by the state or participating in a state-sponsored volunteer program, might encourage health care workers to follow the clinical protocols proposed for ventilator allocation in an influenza pandemic.

However, defense or indemnification or both - without immunity may be inadequate to convince health care workers to follow the Ventilator Guidelines. Health care providers against whom a claim is brought would still be required to endure the time and burdens associated with a lawsuit. Likewise, health care providers' reputations would suffer because identities of providers named in malpractice settlements or payments must be reported to a national data bank. ${ }^{75}$ Moreover, such an expansion of the state's obligations under Section 17, without any immunity for the newlycovered defendants, would expose the state to potentially enormous unbudgeted costs.

\section{Federal and New York State Law Offers Inadequate Liability Protections}

In summary, existing liability protections are a patchwork of federal and state law, which provides limited immunity from civil liability for volunteers. The laws' civil indemnity and defense protections are more extensive than civil immunity protections, and their civil liability protections are much more extensive than their criminal liability protections. Moreover, liability protections are broader for individuals than for entities.

New York's piecemeal and varied approach to providing liability protections for health care providers and entities in a disaster emergency is

74. N.Y. PuB. OFF. LAW § 17(3)(a) (McKinney 2012). New York City separately indemnifies volunteers for noncriminal actions by providing legal representation to caregivers in case of litigation. N.Y. PUB. OFF. LAW § 18(1)(b) (McKinney 2012).

75. Judith C. Ahronheim, Service by Health Care Providers in a Public Health Emergency: The Physician's Duty and the Law, 12 J. Health CARE L. \& POL'Y 195, 233 (citing 42 U.S.C. \$ 11131(a)-(b) (2006)

(requiring reports on medical malpractice payments)). 
inadequate. The Disaster Act does not immunize private health care workers; the Good Samaritan laws do not immunize health care providers within hospitals or compensated actors with a prior duty of care to the patient; and Public Officers Law Section 17 does not provide defense or indemnification to those who are not state employees or volunteers expressly authorized to participate in a state-sponsored volunteer program. ${ }^{76}$ In the majority of cases, New York State laws will not apply to those who will be called upon to provide care pursuant to the Guidelines - those who are privately employed in a hospital with a preexisting duty of care to patients. ${ }^{77}$ Compensated health care providers who continue to perform their professional responsibilities during a declared emergency constitute "an often ignored segment of the responder population."78 The existing approach to

76. The definition of "volunteer" can influence the extent to which health care workers are protected in a declared emergency. See Evan D. Anderson \& James G. Hodge, Emergency Legal Preparedness Among Select US Local Governments, 3 (Suppl. 2) Disaster Med. \& Pub. Health PreParedness S1, S5 (2009) ("How localities legally define the term volunteer directly affects the extent to which local governments can protect VHPs from liability in declared emergencies"). Most states' - including New York's - liability protections are limited in scope and coverage, extending protections only to unpaid "volunteers" or state actors (who are protected under sovereign immunity laws) and excluding paid health care workers who render care under existing employment or as an independent contractor during a health care crisis. N.Y. PUB. HEALTH LAW $\S 3013$ (McKinney 2012) provides liability immunity for uncompensated first responders who render care in an emergency. See also ConN. GEN. STAT. § 28-13 (2010) (conferring immunity and Attorney General defense only to volunteer members of specific entities comprised of medical and public health volunteers, except in cases of willful misconduct). Although City of New York ordinances also do not define "volunteer," New York State law defines "city employees" to include volunteers expressly authorized to participate in City-sponsored volunteer programs. N.Y. PUB. OFFICERS LAW $\S 18(1)(b)$ (McKinney 2012). As noted earlier, the federal VPA offers limited immunity to volunteers who are compensated less than $\$ 500$ per year who serve nonprofit organizations and government entities in certain circumstances. 42 U.S.C. § 14505(6) (1999). Likewise, the Uniform Emergency Volunteer Health Practitioners Act ("UEVHPA"), which New York State has not adopted, extends civil liability protections to registered health care volunteers similar to the immunity provided to state employees under the Emergency Management Assistance Compact ("EMAC"). Nat'l Conference of Comm'rs on Unif. State Law, The Uniform Emergency Volunteer Health Practitioners Act, $\$ 2(15)$ (2006), available at http://www.law.upenn.edu/bll/archives/ulc/uiehsa/2007act_final.pdf. The UEVHPA defines "volunteer health practitioners" to constitute a "health practitioner who provides health or veterinary services, whether or not the practitioner receives compensation for those services" except those who "receive[] compensation pursuant to a preexisting employment relationship with a host entity or affiliate which requires the practitioner to provide health services in this state." Uniform Emergency Volunteer Health Practitioners Act (UEVHPA): An Overview, CENTERS FOR LAW \& THE PUBLIC'S HEALTH at 2 , at http://www.publichealthlaw.net/Research/PDF/ESAR\%20VHP\%20UEVHPA.pdf (last visited Feb. 5, 2013).

77. See Hoffman, supra note 33, at 1917, 1959 (arguing that "exclusion of paid workers and entities from immunity protection is imprudent because it creates barriers to effective emergency response initiatives..." and "raises important questions of justice," and recommending legislation ensuring that "health care providers will not be liable for injuries or harm caused by good-faith actions undertaken in order to respond to a public health emergency so long as they are acting in their capacity as employers or employees in the affected area or volunteering under the direction of governmental authorities or nonprofit organizations, and are not engaged in willful misconduct, gross negligence, or criminal activity.”).

78. Id. at 1917. In contrast, Virginia provides arguably the most extensive immunity protections in the United States, including offering protections to health care workers in a declared state of emergency, regardless of pay. VA. CODE ANN. § 8.01-225.02 (2011) ("In the absence of gross negligence or willful misconduct, any health care provider who responds to a disaster shall not be liable for any injury or wrongful 
immunity and indemnity is insufficient to protect those health care workers and entities who "bear the brunt of the burden" in delivering care during a disaster emergency. ${ }^{79}$

\section{REGULATION OR LEGISLATION?}

Law and regulations, due to their static and binding nature, are not an ideal delivery system for clinically-detailed recommendations, particularly in rapidly-changing circumstances, such as a pandemic. Consequently, voluntary, non-binding guidelines based on "sound ethical and clinical principles" would be the best means of ensuring an effective ventilator allocation system, while avoiding unforeseen consequences. ${ }^{80}$ Accordingly, New York chose to issue its draft recommendations for ventilator allocation in the form of guidelines. However, while guidelines recommending modifications to the standards for the normal delivery of care may be optimal for purposes of flexibility and tailoring clinical behavior to the precise nature of the disaster, they afford the least amount of legal protection to practitioners because of their non-binding nature.

If a pandemic were to occur today, health care providers and entities in New York would have limited recourse if sued for adhering to the Ventilator Guidelines. However, proof of compliance with the Guidelines might still constitute presumptive (rebuttable) or non-conclusive evidence of the legal standard of care - a defense to a claim of negligence. ${ }^{81}$ Guidelines for appropriate treatment protocols during public health emergencies

death of any person arising from the delivery or withholding of health care when (i) a state or local emergency has been or is subsequently declared in response to such disaster, and (ii) the emergency and subsequent conditions caused a lack of resources, attributable to the disaster, rendering the health care provider unable to provide the level or manner of care that otherwise would have been required in the absence of the emergency and which resulted in the injury or wrongful death at issue.") (emphasis added). Commentators in other states have advocated for using Virginia's legislation as a model for protecting health care providers who provide care in a crisis. See Stephen P. Williams \& Haynsworth Sinkler Boyd, Is There Much Limited Legal Liability Protection for Physicians in Crisis Standards of Care in SC? 107 J.S.C. MED. ASSOC. 96 (2011).

79. Hoffman, supra note 33, at 1918, 1953 (calling existing immunity schemes "piecemeal, incomplete, and confusing").

80. Ventilator Guidelines, supra note 1, at 3.

81. Theodore R. LeBlang, Medical Malpractice and Physician Accountability: Trends in the Courts and Legislative Responses, 4 ANN. HEALTH L. 105, 118-120 (1994). It may be argued that even without an explicitly delineated crisis standard of care, the existence of a public health emergency may still be considered a relevant "circumstance" that the jury could consider in deciding liability. See Department of Health \& Human Services, Emergency System for Advance Registration of Volunteer Health Professionals (ESAR$V H P)$ - Legal and Regulatory Issues, CENTERS FOR LAW \& THE PUBLIC'S HEALTH, at 43, at http://www.publichealthlaw.net/Research/PDF/ESAR\%20VHP\%20Report.pdf ("The circumstances related to the emergency as a whole play a factor in establishing the standard of care for the physicians and medical staff rendering care."). See Williams \& Boyd, supra note 78, at 97 ("the accepted consensus by [licensed health care professionals] and professional organizations on Pandemic Flu Guidelines ("PFGs") likely aid in successfully defending a medical malpractice lawsuit after the pandemic ends..."). 
developed by organizations may be "useful in litigation for the purpose of determining whether health professionals acted appropriately and are entitled to immunity." 82 Thus, the Guidelines may serve as departmentally promulgated "soft law," ${ }^{83}$ providing strong evidence of an established standard of care that could reasonably be expected of health care providers in a disaster emergency. ${ }^{84}$

Such deference to professional standards of conduct in the form of policies, codes, and guidelines is not without precedent. ${ }^{85}$ For years, tort reformers have argued for the use of clinical practice guidelines ("CPGs") as evidence of the standard of care in medical malpractice cases. ${ }^{86}$ In response, some states have legislated that guidance developed by expert consensus demonstrate, or are evidence of, the standard of care in civil liability cases. ${ }^{87}$

82. Hoffman, supra note 33, at 1962. Hoffman continues, "[c]onversely, those who deviated from wellestablished emergency procedures will be found to have engaged in gross negligence or willful misconduct." Id. at 1963. See also ANA Issue Brief: Who Will be There? Ethics, the Law, and a Nurse's Duty to Respond in a Disaster, AMERICAN NURSES ASSOCIATION (2010), available at http://www.nursingworld.org/MainMenuCategories/WorkplaceSafety/DPR/Disaster-Preparedness.pdf; Adapting Standards of Care Under Extreme Conditions: Guidance for Professionals During Disasters, Pandemics, and Other Extreme Emergencies, AMERICAN NURSES ASSOCIATION (2008), available at http://www.nursingworld.org/MainMenuCategories/WorkplaceSafety/DPR/TheLawEthicsofDisasterRespo nse/AdaptingStandardsofCare.pdf.

83. Angela Campbell \& Kathleen Cranley Glass, The Ethical Status of Clinical and Ethics Policies, Codes, and Guidelines in Medical Practice in Research, 46 MCGILL L.J. 473 (2001).

84. Ventilator Guidelines, supra note 1. See also Institute of Medicine, Guidance for Establishing Crisis Standards of Care for Use in Disaster Situations, 49 (2009) (recommending that states "explicitly tie existing liability protections... for health care practitioners and entities to crisis standards of care.”). The Ventilator Guidelines would also likely be non-conclusive evidence of the standard of care in professional disciplinary proceedings.

85. Campbell \& Glass, supra note 83, at 476. See, e.g., Frakes v. Cardiology Consultants PC, 1997 Tenn. App. LEXIS 597 (1997) (finding that guidelines issued by the American College of Cardiology and the American Health Association for interpreting exercise treadmill tests administered to patients, supported by expert testimony, represent the standard of care for the profession).

86. See Michelle M. Mello, Of Swords and Shields: the Role of Clinical Practice Guidelines in Medical Malpractice Litigation, 149 U. PA. L. REV. 645, 648 (2001) (proposing that "while there may be certain efficiencies associated with the use of CPGs as the legal standard of care, their use is deeply problematic" due to their permitted use only as exculpatory evidence (by physician defendants) and not as inculpatory evidence (by plaintiffs)); Richard E. Leahy, Comment, Rational Health Policy and the Legal Standard of Care: A Call for Judicial Deference to Medical Practice Guidelines, 77 CAL. L. REv. 1483 (1989). The Institute of Medicine defines CPGs as "statements that include recommendations intended to optimize patient care that are informed by a systematic review of evidence and an assessment of the benefits and harms of alternative care options." Committee on Standards for Developing Trustworthy Clinical Practice Guidelines, Institute of Medicine, Clinical Practice Guidelines We Can Trust 4 (Robin Graham, Michelle Mancher, Dianne Miller Wolman, Sheldon Greenfield, \& Earl Steinberg, eds., 2011).

87. Mello, supra note 86 , at 665 (" $[\mathrm{t}]$ he prevailing practice is to admit CPGs in connection with expert testimony, but not to give them determinative weight."). Mello provides a useful summary of the various proposals for giving guidelines a greater role in negligence litigation, including the "contract model," the "judicial notice model" (which proposes that courts take judicial notice of CPGs as representing the legal standard of care), and the "Maine model." Id. From 1992 until 1996, a Maine statutory demonstration project created an absolute affirmative defense to medical malpractice claims for physicians who demonstrated compliance with specific practice guidelines. 24 ME. REV. STAT. ANN. tit. §§ 2971-2979 (repealed 
Likewise, some state courts allow industry codes and standards to be admitted in support of a defense to medical malpractice. Many states, including New York, recognize these codes and standards as probative - not conclusive - evidence on the issue of the defendant's duty. ${ }^{88}$ New York courts have held that, even with evidence that a health care provider complied with state guidelines, there may still be an issue regarding whether the proper standard of care has been met. ${ }^{89}$

Thus, demonstrating that a health care provider or entity followed the Guidelines would only constitute evidence of meeting the standard of care, but would not insulate that individual or entity from suit. ${ }^{90}$ Moreover, although guidelines may be evidence of the standard of care or may serve as an affirmative defense in negligence proceedings, courts may be unwilling to hold that declining to follow them would amount to gross negligence or professional misconduct. ${ }^{91}$

1999). Kentucky's statute, which is still in effect, protects physicians who follow CPG protocols that have been adopted by the health commissioner. KY. REV. STAT. ANN. § 342.035(8) (a)-(b) (West 2010) (“(a) ...The commissioner may adopt any parameters for clinical practice as developed and updated by the federal Agency for Health Care Policy Research, or the commissioner may adopt other parameters for clinical practice which are developed by qualified bodies, as determined by the commissioner, with periodic updating based on data collected during the application of the parameters. (b) Any provider of medical services under this chapter who has followed the practice parameters or guidelines developed or adopted pursuant to this subsection shall be presumed to have met the appropriate legal standard of care in medical malpractice cases regardless of any unanticipated complication that may thereafter develop or be discovered."). Draft Massachusetts guidelines also suggest that reliance on guidance will serve as evidence of having met the crisis standard of care and state that an individual patient to whom an approved crisis standard of care is provided should have no basis to assert in a medical malpractice claim against the health care provider that an appropriate level of care was not provided. Levin, supra note 58, at S138 ("Moreover, the [health care provider], having met the requisite standard of care, should not be held liable in a malpractice action based on the provision of care in accordance with an approved" crisis standard of care).

88. See Bailey v. Bakers Air Force Gas Corp., 376 N.Y.S.2d 212 (App. Div. 3d Dep’t 1975). See also Daniel E. Feld, Annotation, Admissibility in Evidence, on Issue of Negligence, of Codes or Standards of Safety Issued or Sponsored by Governmental Body or by Voluntary Association, 58 A.L.R.3d 148, 155 (1974) (summarizing the varying approaches to the admissibility of safety codes or standards).

89. See Sherman v. M. Lowenstein \& Sons, 282 N.Y.S.2d 142 (App. Div. 2d Dep’t 1967) (holding that compliance with federal and state flammability-testing methods was some evidence of due care, but was not conclusive).

90. See also Memorandum from Henry Greenberg to Public Health Council's Ad Hoc Committee on Quality Assurance in Office-Based Surgery, Statutory and Regulatory Authority Over Office-Based Surgery (May 11, 1998) (on file with author). Greenberg further notes that "[w]hile neither strict compliance with, nor deviation from, the [office-based surgery] guidelines would be dispositive, the guidelines could be important as a benchmark for professional practice." $I d$.

91. See, e.g., N.Y. State Ass'n of Nurse Anesthetists v. Novello, 810 N.E.2d 405 (N.Y. 2004). The New York State Association of Nurse Anesthetists sought a declaration that the Department of Health's Clinical Guidelines for Office-Based Surgery were null and void because they are, in fact, regulations, promulgated outside of the Department's authority. Despite the Supreme Court and Appellate Division both holding that the guidelines were regulations and that their promulgation was outside the scope of the Department's authority, the Court of Appeals reversed and dismissed for lack of standing, without reaching the merits of the substantive claim. 


\section{APPROACHES TO MITIGATING CIVIL LIABILITY}

Recognizing the dearth of existing protections for health care providers and entities that adhere to the Guidelines, there are a number of possible approaches to providing protections from civil liability. Legislation conferring immunity upon health care providers and entities that provide care in a pandemic pursuant to the Guidelines may offer the most protection, and therefore, be most effective in encouraging compliance with the ventilator allocation protocol. However, various additional options - implemented either alone or in combination with each other - merit consideration as approaches to mitigating civil liability.

\section{A. Immunity-Conferring Legislation}

Guidelines, such as the Ventilator Allocation Guidelines, recommend shifting scarce resources in order to save the most lives possible, rather than focusing on the individual. ${ }^{92}$ It is well understood that the provision and scope of care may reasonably change according to the circumstances of a disaster. ${ }^{93}$ However, in an emergency, the declaration of a modified medical standard of care may enable health care providers to more easily demonstrate that they met the requisite level of care in order to avoid civil liability. ${ }^{94}$ The establishment of immunity-conferring protections for

92. Health Sys. Research, Inc., AHRQ Pub. No. 05-0043, Altered Standards of Care in Mass Casualty Events, at 8 (2005), available at http://archive.ahrq.gov/research/altstand/altstand.pdf [hereinafter "AHRQ"] (the AHRQ's Public Health Emergency Preparedness ("PHEP") program was discontinued on June 30, 2011).

93. See George Annas, Standard of Care - In Sickness and in Health and in Emergencies, 362 NEw ENGL. J. MED. 2126 (2010); Mark A. Rothstein, Malpractice Immunity for Volunteer Physicians in Public Health Emergencies: Adding Insult to Injury, 38 J. L. MED. \& ETHICS 149, 150 (2010) (“[I]n stark contrast to suggestions by some 'altered standards of care' advocates, the current standard of care applied to all medical malpractice cases is sufficiently flexible and situation-specific that it need not be altered"); Hoffman, supra note 33; Kristi L. Koenig, et al., Crisis Standards of Care: Refocusing Health Care Goals During Catastrophic Disasters and Emergencies, 3 J. EXPERIMENTAL \& CliniCAL MED. 159, 161 (2011) ("Being a flexible doctrine, it is the same regardless of the circumstances - understood simply as doing what you can under the circumstances, with the patient's informed consent"). But see Darren P. Mareiniss et al., ICU Triage: The Potential Legal Liability of Withdrawing ICU Care During a Catastrophic Event, 6 AM. J. DisASTER MED. 329 (2011) (arguing that relying on the flexibility of the legal standard of care may be inadequate and therefore special immunities and protections may be required).

94. See, e.g., Brooke Courtney, Emergency Legal Preparedness and the Public's Health: Five Legal Preparedness Challenges for Responding to Future Public Health Emergencies, 39 J. L. MED. ETHICs 60, 6162 (2011); CDC Public Health Law Program, After-Action Report: Legal Issues and the H1N1 Influenza Pandemic, National Association of County \& City Health OfFicials, 13 (Apr. 30, 2010), at http://www.naccho.org/topics/H1N1/upload/043010-H1N1-Legal-Issues-After-Action-Report.pdf (identifying the "[n]ecessity of term "Crisis" or "Altered" Standards of Care for medical professionals during a public health emergency" and the "legal authority for standards of care" as outstanding legal issues to be addressed); Mareiniss, supra note 93, at 332 (focusing on the flexibility of the legal standard of care because informed consent would be violated when providers proceeded with the "unconsented" reallocation of ICU resources in a pandemic). 
health care providers and entities who follow the Guidelines, coupled with the declaration of a crisis medical standard of care, would facilitate consistency in application and enable the avoidance of unpredictable outcomes when legal disputes occur. ${ }^{95}$ Thus, official public state acknowledgment of a crisis standard of care in an emergency would ensure forethought in decision-making and consistency in the application of the Guidelines, as well as ease the burden on health care workers who seek to prove non-negligent behavior after the disaster has passed.

New, clear legislation that provides reduced liability is the most effective way to protect practitioners who follow the Guidelines. ${ }^{96}$ Because the Guidelines themselves are purely advisory and do not carry the force of law, ${ }^{97}$ legislation could render adherence conclusive (irrebuttable) evidence of compliance with the standard of care, potentially serving as the basis for a dismissal of the complaint without trial. Therefore, this approach would maintain the voluntary nature of the clinical guidelines in combination with the promulgation of immunity-conferring legislation to protect health care workers and entities. ${ }^{98}$

Legislation extending liability protections should include limitations like a good faith requirement and exclusions for certain acts of gross neg-

95. Levin, supra note 58, at S133 (describing altered standards of care as "standards that are acceptable when adequate resources are not available to meet the usual standard of care" furnished by health care providers). See also Brooke Courtney \& James G. Hodge, Legal Considerations During Pediatric Emergency Mass Critical Care Events, 12 PEDIATR. CRIT. CARE MED. S152, S154 (2011).

96. For an example of extensive immunity protections for care provided in an emergency, see VA. CODE ANN. § 8.01-225.02 (2011) ("In the absence of gross negligence or willful misconduct, any health care provider who responds to a disaster shall not be liable for any injury or wrongful death of any person arising from the delivery or withholding of health care when . . . the emergency and subsequent conditions caused a lack of resources, attributable to the disaster, rendering the health care provider unable to provide the level or manner of care that otherwise would have been required in the absence of the emergency and which resulted in the injury or wrongful death at issue.") (emphasis added). Virginia's law was crafted to establish a crisis standard of care and confer immunity on health care providers based on this standard.

97. "If there were to be fixed standards in regulations for physician [private practice], there would need to be some enforcement mechanisms in order to ensure compliance." Greenberg, Statutory and Regulatory Authority Over Office-Based Surgery, supra note 90. Thus, if Department-issued guidelines were to amount to a "fixed, general principle," they would be considered improperly promulgated regulations because the New York State Department of Health does not generally have authority to regulate the practice of medicine, regardless of what they are called. N.Y. State Ass'n of Nurse Anesthetists v. Novello, 753 N.Y.S.2d 615 (App. Div. 4th Dep't 2003). In Novello, the Appellate Division noted that the Department of Health had intended its office based surgery guidelines to "represent uniform professional standards of care and may help to clarify a practitioner's obligations under law and regulation." Based on this fact, the court concluded, "[i]n our view, on its face this assertion suggests that the Guidelines, however self-named or characterized, are regulations." Id.

98. Ventilator Guidelines, supra note 1 ("The combination of voluntary guidelines based on sound ethical and clinical principles, paired with legislation that protects providers who comply with the guidelines, offers the best possible balance of clarity, flexibility, and confidence in designing public health policy for allocating ventilators in a pandemic"). For examples of the most broad immunity-conferring legislation currently in effect, see VA. CODE ANN. § 8.01-225.02 (2008); MD. PuB. SAFETy CODE ANN. § 14-3A-06 (2004). 
ligence or willful misconduct. ${ }^{99}$ However, arguably, immunity-conferring statutes that exempt "willful misconduct" may not adequately protect health care providers who remove ventilator therapy from a patient consistent with state-promulgated guidelines. Such an act might be considered to be willful or in conscious disregard of the safety of the individual harmed and therefore beyond the protective scope of the law. ${ }^{100}$ Thus, special consideration should be given to ensure that any immunityconferring legislation does not limit the ability for any individual or hospital to withdraw certain medical equipment pursuant to the Guidelines.

However, such legislation may be practically and politically difficult to realize, particularly without identification of the scope of behavior that it is intended to protect. Moreover, it would not insulate health care workers from liability for breaches of federal law or federal constitutional claims alleging violations of due process, equal protection, or takings law.

\section{B. Caps on Damages}

Legislation imposing a cap on damages in liability cases arising out of declared emergencies (or for those who, in particular, abide by the Guidelines) could offer some protections for health care workers, thereby encouraging adherence to the Guidelines. Commentators have noted that damages caps "have been found to generate small increases in the supply of physicians," which demonstrates that "diminished concerns about liability are associated with greater willingness on the part of individuals to serve as health care providers." 101 Many states have already instituted damages caps in liability cases arising out of malpractice claims generally. ${ }^{102}$ However, some states - but not New York - have found caps on noneconomic damages to be unconstitutional. ${ }^{103}$ The subject of damages

99. In most states that confer liability protections in an emergency, their laws shield health care workers from negligence liability, but not gross negligence. But see Mareiniss, supra note 93, at 333 (noting that Black's Law Dictionary “defines willful, reckless, wanton, and gross negligence as acts that are intentionally done despite the known risk that it is 'highly probable that harm will follow"').

100. Mareiniss, supra note 93 , at 333.

101. Hoffman, supra note 33 , at 1956

102. As of 2010, twenty-eight states had laws limiting damages in malpractice cases. Medical Liability/Malpractice Laws, NATIONAL CONFERENCE OF STATE LEGISLATURES (Sept. 23, 2010), available at http://www.ncsl.org/default.aspx?tabid=18516. See, e.g., FL. STAT. § 766.118 (2011) (noneconomic damages limited to $\$ 500,000$ per claimant); S.C. CODE $\$ 15-32-220$ (a) (2010) (noneconomic damages limited to $\$ 350,000$ against single health care provider or facility); BURNS IND. CODE ANN. $\$ 34-18-14-3$ (2011) (a health care provider is not liable for an amount in excess of $\$ 250,000$ for an occurrence of malpractice); Miss. CODE ANN. § 11-1-60(2)(a) (2010) (\$500,000 maximum non-economic per plaintiff; the state also has caps for liability in providing emergency care, also often barred from bringing claims of negligence; only gross negligence). See also Fred J. Hellinger \& William E. Encinosa, The Impact of State Laws Limiting Malpractice Damage Awards on Health Care Expenditures, 96 AM. J. PuBliC HEALTH 1375 (2006).

103. See, e.g., Brannigan v. Usitalso, 587 A.2d 1232 (N.H. 1991) (finding that the $\$ 875,000$ cap on non- 
caps in New York has been the subject of much debate, although the state currently has no applicable statute imposing any damage award limits or caps in tort suits. ${ }^{104}$ Nevertheless, despite the resistance to damages caps for medical malpractice cases arising out of routine care, it may be more palatable to institute them for care provided in emergency situations.

\section{Expedited Discovery and Statutes of Limitations}

Under existing law, it is within the discretion of the court to set the schedule for discovery. ${ }^{105}$ In order to ease the burden on individuals and entities who comply with the Ventilator Guidelines, courts could expedite the initial phase of discovery in tort suits arising out of circumstances related to a public health disaster and limit discovery to the production of evidence that the Guidelines were followed. ${ }^{106}$ New legislation could require New York State courts to exercise their power to order discovery to take place in stages, limiting initial discovery to the issue of compliance with the standard of care applicable in a disaster emergency where the Guidelines were followed. The health care provider or entity defendant could then move for summary judgment or dismissal before being required to undergo further discovery on additional issues.

Instead of requiring that discovery occur in stages, courts could alternatively limit discovery in tort claims arising from a state of declared

economic damages violated the equal protection provision of the state constitution); Ferdon $v$. Wis. Patients Comp. Fund, 701 N.W.2d 440 (Wis. 2005) (finding that a \$350,000 cap on noneconomic damages in medical malpractice cases violates the state's equal protection guarantee). But see Evans v. State, 56 P.3d 1046 (Alas. 2002) (finding that the cap did not limit access to the courts, did not infringe on the right to a trial by jury, and did not deny substantive due process, constitute a denial of equal protection, or violate the separation of powers); Fed. Express Corp. v. U.S., 228 F. Supp. 2d 1267 (N.M. 2002) (holding that the cap was not arbitrary and capricious in limiting deserving plaintiffs from deserved relief, and that was rationally related to the legislative goal of ensuring a source of recovery for victims of medical malpractice and curbing runaway costs of health care).

104. New York allows punitive damages without limitation for tort actions. See Pearlman v. Friedman Alpren \& Green LLP, 750 N.Y.S.2d 869 (App. Div. 1st Dep't 2002)_(allowing punitive damages for intentional or deliberate wrongdoing, aggravating or outrageous circumstances, fraudulent or evil motive, or conscious act in willful and wanton disregard of another's rights). However, the Appellate Division has a statutory responsibility to reduce excessive damages awards, which is often exercised in medical malpractice cases. N.Y. C.P.L.R. § 5501(c) (McKinney 2012) ("In reviewing a money judgment in an action in which an itemized verdict is required by rule forty-one hundred eleven of this chapter in which it is contended that the award is excessive or inadequate and that a new trial should have been granted unless a stipulation is entered to a different award, the appellate division shall determine that an award is excessive or inadequate if it deviates materially from what would be reasonable compensation").

105. See, e.g., N.Y. C.P.L.R. § 3406 (McKinney 2012)

106. The cases disputing the contours of Governor Pataki's Section 30.30 suspension in response to September 11th give rise to a consideration of what is within the Governor's authority in suspending or modifying certain civil and criminal trial rules. It would seem that changing the discovery rules to streamline or eliminate certain burdens may not always be an available approach. However, extending the discovery period to allow for delays due to a declared emergency may be within the governor's authority. 
emergency. In most state and federal courts, the discovery rules are based on the rules of evidence, which often require a basic balancing test to determine whether discovery may be limited. ${ }^{107}$ New York civil practice law and rules require "full disclosure of all matter material and necessary in the prosecution or defense of an action, regardless of the burden of proof." 108

Alternatively, the statute of limitations for instituting legal action for negligence claims arising out of care rendered during a declared health emergency may be shortened. In New York, the existing statute of limitations for instituting a medical malpractice claim, regardless of the circumstances out of which the claim arises, is 2.5 years. ${ }^{109}$ Shortening this time period for actions arising out of an emergency may lessen the number of health care providers who must defend against a lawsuit.

Thus, although modification of the discovery process and statutes of limitation would provide neither immunity nor indemnity to health care providers and entities, it might lessen the time and resources they expend when defending a suit by diminishing the likelihood of suit, shortening the length of the process, and permitting the dismissal of time-barred actions.

\section{Alternative Resolution Procedures}

The use of alternative dispute resolution procedures and the establishment of substituted methods of handling civil liability suits that might arise from adhering to the Ventilator Guidelines could also ease the potential burdens of litigation on both health care providers and the court sys-

107. In the context of electronically stored information ("ESI"), for example, under the Federal Rules of Civil Procedure, the trial court has the power to limit discovery "if the burden or expense of the proposed discovery outweighs its likely benefit." FED. R. CIV. P. 26. New York Civil Practice Law and Rules have not been modified as the Federal Rules have to address the balancing of burden versus benefit. The Joint Committee has proposed that the advisory notes to N.Y. C.P.L.R. $\$ 3103$ (McKinney 2012) be amended to include the same language as FED. R. CIV. P. 26. The new language would allow a New York court dealing with an ESI discovery dispute to consider "whether the burden or expense of the proposed discovery outweighs its likely benefit, considering the needs of the case, the amount in controversy, the parties' resources, the importance of the issues at stake in the action, and the importance of the discovery in resolving those issues." Norman C. Simon et al., Amending the CPLR to Reflect Changes to the Information Landscape: the Association of the Bar of the City of New York's Proposals (Jan. 4, 2010), available at http://www.lexology.com/library/detail.aspx?g=fbe599b7-5d10-4243-b8efdd92a7d4b8f9. As noted elsewhere, the New York State legislature has no power to govern federal decisions.

108. N.Y. C.P.L.R. § 3101(a) (McKinney 2012). However, a search of case law did not identify any instances where discovery rules were altered for particular fact patterns.

109. N.Y. C.P.L.R. § 214(a) (McKinney 2012) ("An action for medical, dental or podiatric malpractice must be commenced within two years and six months of the act, omission or failure complained of or last treatment where there is continuous treatment for the same illness, injury or condition which gave rise to the said act, omission or failure."). Lawsuits based on intentional torts, such as battery, have a statute of limitations of one year. N.Y. C.P.L.R. § 215(3) (McKinney 2012). 
tem. Claims related to health care provided during an emergency could be: (1) settled by arbitration; (2) subject to pretrial review panels; or (3) ameliorated by covering injuries with monies gathered in a compensation pool in lieu of instituting suit. Each approach has advantages and limitations.

\section{Arbitration}

Arbitration is generally less expensive, time-consuming, and burdensome than litigation, although there is conflicting evidence regarding whether arbitration leads to more frequent findings of liability and higher damages awards than litigation. ${ }^{110}$ Arbitration may not lead to fewer proplaintiff judgments or lower damages, but there is reason to believe that it would decrease transaction costs and certain burdens associated with litigation, particularly those associated with longer discovery periods. ${ }^{111}$

Although no state has yet adopted an arbitration board to review cases arising out of pandemics or other emergencies, ${ }^{112}$ New York could legislatively require cases arising out of circumstances associated with a declared disaster emergency to be subject to binding arbitration. Importantly, however, courts have noted the crucial distinction between voluntary and compulsory arbitration, the latter of which is particularly subject to constitutional attacks. Although compulsory binding arbitration is not per se unconstitutional, ${ }^{113}$ in some cases it may violate the Seventh Amendment right to a jury trial ${ }^{114}$ and/or impinge on due process guaran-

110. Compare David S. Schwartz, Enforcing Small Print to Protect Big Business: Employee and Consumer Rights Claims in an Age of Compelled Arbitration, 33 WIS. L. REV. 33, 60-61 (1997) (arguing that corporate defendants prefer arbitration because, among other things, it generally yields lower damage awards, reduces defense costs, and eliminates pretrial discovery) with Stephen J. Ware, The Case for Enforcing Adhesive Arbitration Agreements - With Particular Consideration of Class Actions and Arbitration Fees, $5 \mathrm{~J}$. AM. ARB. 251, 261 (2006) (noting that small meritorious claims, some of which might not be cost effective in litigation, may see higher awards in arbitration).

111. Keith N. Hylton, Agreements to Waiver or to Arbitrate Legal Claims: An Economic Analysis, 8 SuP. Ct. ECON. Rev. 209 (2000); Steven Shavell, Alternative Dispute Resolution: An Economic Analysis, 24 J. LEG. STUD. 1 (1995). However, some research has found that arbitration does not lower transaction costs. See Public Citizen, Cost of Arbitration: Executive Summary, Law Memo: First in Employment Law (May 1, 2002), available at http://www.lawmemo.com/arb/res/cost.htm.

112. Kristine M. Gebbie et al., Adapting Standards of Care Under Extreme Conditions, 3 DiSASTER MED. \& Pub. HEALTH PREPAREDNESS 111, 115 (2009).

113. Andrews v. Louisville \& Nashville R.R., 406 U.S. 320, 322 (1972); Textile Workers Pension Fund v. Standard Dye \& Finishing Co., 725 F.2d 843, 857-58 (2d Cir. 1984); Lyeth v. Chrysler Corp., 734 F. Supp. 86 (W.D.N.Y. 1990) (finding lemon law constitutional because arbitrators were independent and impartially chosen, and arbitration hearings were governed by a myriad of procedural safeguards).

114. Although the Seventh Amendment right to a trial by jury only applies to federal cases, the New York State Constitution also provides for a right to trial by jury. U.S. CONST. amend. VII ("In suits at common law, where the value in controversy shall exceed twenty dollars, the right of trial by jury shall be preserved ...."); N.Y. ConsT. art. I § 1 ("No member of this state shall be ... deprived of any . . . rights or privileges . . . unless by the law of the land, or the judgment of his or her peers ...."). Additionally, a case brought 
tees. ${ }^{115}$ Commentators have noted that "the paucity of decisions" regarding the legality of compulsory arbitration "in cases involving such statutes bars the formulation of any general rule as to their constitutionality." 116

New York courts have found that compulsory binding arbitration is constitutional, but the arbitrator's determination must be subject to "closer judicial scrutiny"than for determinations made in voluntary arbitration. ${ }^{117}$ For example, courts have held that the legislature can, in the interest of public health and welfare, requirethe settlement of labor disputes in nonprofit hospitals through compulsory and binding arbitration, provided there is substantive and procedural due process of law. ${ }^{118}$ Courts have also held that New York's new car "lemon law," which establishes a compulsory arbitration process, satisfies the minimal requirements of due process, because litigants are entitled to receive judicial review under the arbitrary and capricious standard enunciated in New York civil procedural rules. ${ }^{119}$

The easiest way to avoid constitutional attacks would be to allow on-

in or removed to federal court may require a jury trial pursuant to the Seventh Amendment even if the underlying cause of action sounds in state law. Simler v. Conner, 372 U.S. 221, 222 (1963) (finding "that the right to a jury trial in the federal courts is to be determined as a matter of federal law in diversity . . . actions. The federal policy favoring jury trials is of historic and continuing strength."). See also Henry Cohen \& Vanessa Burrows, Congressional Research Service Report 95-797, Federal Tort Reform Legislation: Constitutionality and Summaries of Selected Statutes (2008), available at http://assets.opencrs.com/rpts/95797_20080929.pdf.

115. The due process guarantees of the United States Constitution apply at both the federal and state levels. U.S. CONST. amend. V ("No person shall... be deprived of life, liberty, or property, without due process of law ...."); id. at amend. XIV ("[N]or shall any State deprive any person of life, liberty, or property, without due process of law ....").

116. R.D. Hursh, Annotation, Constitutionality of Arbitration Statutes, 55 A.L.R.2d 432 (2009). The labor disputes at issue are often ones deciding that such requirements be applicable only to labor disputes affected with a real public interest and they meet the tests traditionally applied to administrative regulation and determination of private rights and duties.

117. See Mount St. Mary's Hosp. of Niagara Falls v. Catherwood, 26 N.Y.2d 493, 500 (1970) ("At the inception it should be observed that the essence of arbitration, as traditionally used and understood, is that it be voluntary and on consent. The introduction of compulsion to submit to this informal tribunal is to change its essence ... It is very easy to transfer, quite fallaciously, notions and principles applicable to voluntary arbitration to 'compulsory' arbitration, because, by doubtful logic but irresistible usage, both systems carry the descriptive noun 'arbitration' in their names. The simple and ineradicable fact is that voluntary arbitration and compulsory arbitration are fundamentally different if only because one may, under our system, consent to almost any restriction upon or deprivation of right, but similar restrictions or deprivations, if compelled by government, must accord with procedural and substantive due process"); In re Progressive Cas. Ins. Co. v. N.Y. State Ins. Fund, 47850 N.Y.S.2d 478 (App. Div. 2nd Dep’t 2008).

118. Requiring compulsory arbitration of malpractice cases arising from circumstances of a disaster emergency would also require appropriate checks on the amount of damages that could be awarded so as not to exceed the authority conferred upon the legislature by the state constitution. Mount St. Mary's Hosp. of Niagara Falls, 26 N.Y.2d at 493 (finding due process requirements had been satisfied because the decision was reviewable if the arbitrator acted beyond his authority); In re Long Island Coll. Hosp. v. Catherwood, 283 N.Y.S.2d 249 (Spec. Term 1967), judgment aff'd, 283 N.Y.S.2d 1014 (App. Div. 1st Dep't 1967), judgment aff'd as modified on other grounds, 287 N.Y.S.2d 313 (App. Div. 1st Dep't 1968), order rev'd on other grounds, 23 N.Y.2d 20 (1968). See also City of Amsterdam v. Helsby, 37 N.Y.2d 19 (1975); City of Buffalo v. N.Y. State Pub. Emp. Rel. Bd., 363 N.Y.S.2d 896 (Sup. Ct. 1975).

119. Lyeth v. Chrysler Corp., 929 F.2d 891, 895-896 (2d Cir. 1991). 
ly voluntary arbitration (thereby avoiding the jury trial issue) with review de novo in the courts (thereby avoiding the due process issue). ${ }^{120}$ However, this would obviate the advantages of binding arbitration, as any frustrated party could appeal the decision. In order to preserve the benefits of arbitration, it is important that it be considered "binding" so that the ability to challenge the decision is limited. ${ }^{121}$

\section{Pretrial Review Panels}

Legislation requiring that claims be reviewed by a panel for merit before they are allowed to proceed to litigation is an alternative similar to nonbinding arbitration. Many (if not most) states require a medical review panel determination before the parties can proceed to trial in a medical malpractice case. For example, in Indiana, unless the claimant seeks damages below $\$ 15,000$, an action against a health care provider may not be commenced before the claimant's proposed complaint has been presented to a medical review panel and that panel has issued an opinion. ${ }^{122} \mathrm{Ne}$ braska requires that medical review panels review all malpractice claims against health care providers covered by the Nebraska Hospital-Medical Liability Act in advance of filing a civil action. ${ }^{123}$ The claimant may affirmatively waive his or her right to a panel review, and in such case the claimant may proceed to file his or her action directly in court. ${ }^{124} \mathrm{New}$ York, in contrast, has no pretrial screening procedure.

120. Constitutionality of Arbitration Statutes, 55 A.L.R.2d $432 \S 2[\mathrm{~b}]$ (2009); Carol A. Crocca, Annotation, Arbitration of Medical Malpractice Claims, 24 A.L.R.5th 1 (1994). Other states allow malpractice suits to be determined by nonbinding arbitration. For example, Florida allows either party to a medical malpractice suit to request that the case be submitted to nonbinding arbitration. FL. STAT. $§ 766.107$ (2011). After the arbitration decision is made, any party may demand a trial de novo in the circuit court, where evidence of the arbitration proceeding is not admitted.

121. New York State already allows parties to enter voluntary binding arbitration in lieu of litigation. For example, in medical malpractice cases it is not required. Where arbitration is elected, the same standard of care applies as in a comparable malpractice action. N.Y. C.P.L.R. § 7552(b) (McKinney 2012). A decision of a panel of arbitrators is binding on all parties, unless modified or vacated pursuant to $\S 7509$ or $\S 7511$. New York law also expressly authorizes health maintenance organizations (defined broadly) to agree in writing with their members prior to treatment that all medical malpractice claims will be subject to binding arbitration. Members must be permitted to opt out. N.Y. PUB. HEALTH LAW § 4406-a (McKinney 2012). Where liability is conceded, either party may request arbitration on the amount of damages. N.Y. C.P.L.R. $\S 3045$ (McKinney 2011). New York C.P.L.R. § 7511(b)(1)(iii) (McKinney 2012) authorizes judicial vacatur of arbitration awards where the arbitrator has exceeded his power.

122. BURNS IND. CODE $§ 34-18-8-4$ et seq. (2011).

123. NEB. REV. STAT. § 44-2840 et seq. (2010).

124. NEB. REV. STAT. § 44-2843. "The panel shall, within 30 days, render one or more of the following expert opinions which shall be in writing and mailed to each of the parties: (a) The evidence supports the conclusion that the defendant failed to comply with the appropriate standard of care as charged in the complaint in specified particulars; (b) The evidence supports the conclusion that the defendant involved met the applicable standard of care required under the circumstances; or (c) There is a material issue of fact, not requiring expert opinion, bearing on liability for consideration by the court or jury in specified particulars." 
Pretrial screening panels could serve as a filter, reviewing claims before a suit is filed and permitting only meritorious claims to proceed to litigation. The establishment of a special panel, particularly if comprised of individuals familiar with disaster medicine protocols and New York's Ventilator Guidelines, might serve as an effective screening mechanism which could potentially ease the burden on health care workers who render care pursuant to the Guidelines in a flu pandemic. However, the use of review boards would require convening a group of specialized volunteers willing to review a potentially large number of cases and identifying where funding will come to hire and pay reviewers.

\section{Compensation Pools}

Establishment of a non-judicial compensation pool for use as a nofault method of claim settlement might decrease the likelihood of litigation and lessen the burden on potential litigants. ${ }^{125}$ Individuals injured due to a health care provider's or entity's adherence to the Guidelines would seek redress through the fund in lieu of bringing suit.

The effective use of both federal and other states' compensation pools might serve as a model for one in New York State. For example, the PREP Act provides for the establishment of an emergency fund designed to compensate aggrieved individuals for certain injuries associated with the "covered countermeasures" addressed in the statute. ${ }^{126}$ An aggrieved individual can either "accept the compensation or. . . bring an action under" the PREP Act, but cannot do both. Similarly, other federal compensation programs have been established to immunize private parties, while eliminating the claimant's right to sue. The 1986 National Childhood Vaccine Injury Act established that claims for injuries are first decided by the "Vaccine Court" (the Court of Federal Claims). ${ }^{127}$ The statute prohibits suits under state tort law against manufacturers and administrators of specified vaccines unless the claimant first files a claim for limited no-fault compensation (e.g., a $\$ 250,000$ cap on pain and suffering) with the $\mathrm{Na}$ tional Vaccine Injury Compensation Program, which is administered by a director selected by the Secretary of HHS. Claims are paid by the Vaccine Injury Compensation Trust Fund, which is funded by a tax on vaccines.

125. See, e.g., James G. Hodge et al., The Legal Framework for Meeting Surge Capacity Through the Use of Volunteer Health Professionals During Public Health Emergencies and Other Disasters, 22 J. CONTEMP. L. \& POL'Y 5, 68 (2005).

126. 42 U.S.C. $§ 247 d-6 c(a)$ (2004); Hoffman, supra note 33, at 1945. The PREP Act created a new section (319F-4) of the Public Health Service Act, which would establish in the Treasury the "Covered Countermeasure Process Fund."

127. 42 U.S.C. $\S 300 a a-22(c)(1987)$. 
However, the statute does not bar all suits; a claimant dissatisfied with the outcome may then sue under state tort law. Likewise, the September 11th Victim Compensation Fund of 2001 established no-fault compensation for injuries sustained in that disaster. ${ }^{128}$

Various states have also utilized no-fault compensation funds to decrease the administrative costs and burdens of litigation, particularly for medical tort cases. ${ }^{129}$ For example, both Virginia and Florida have established compensation programs to pay for the care of infants born with certain neurological injuries (which are often the most expensive cases). ${ }^{130}$ Virginia's Birth-Related Neurological Injury Compensation Program ("NICP") is funded by hospitals, physicians, and liability insurers who choose to participate in the program; no state funds are used. ${ }^{131}$ Awards issued under the NICP are the exclusive remedy for families, meaning that if an injury is covered by the NICP, the family is not entitled to compensation from other legal action. ${ }^{132}$ Likewise, compensation for injuries under Florida's Birth-Related Neurological Injury Compensation Association ("NICA") is the exclusive remedy, except for cases involving malicious or purposefully negligent actions. ${ }^{133}$ The sources of funds for the pool include participating obstetricians, all other Florida physicians (who pay a lower rate than obstetricians), nonpublic hospitals, and the state of Florida. ${ }^{134}$

New York State could set up a compensation pool similar to the federal and state funds described above for injuries arising out of adherence to the Ventilator Guidelines during a declared state of disaster emergency. ${ }^{135}$

128. 49 U.S.C. $\S 40101$ (2000). The Social Security disability insurance or workers' compensation insurance could also be used as a model for such a compensation system.

129. For an evaluation of no-fault compensation systems for medical injury, see David M. Studdert et al., No-Fault Compensation for Medical Injuries: The Prospect for Error Prevention, 286 JAMA 217 (2001).

130. In 2011, the New York Birth-Related Neurological Impairment Compensation Act was introduced in New York. See S. A2814, 2011 Assemb., 234th Sess. (N.Y. 2011) (proposing the enactment of the New York birth-related neurological injury compensation act; directing the workers' compensation board to determine all claims for compensation for birth-related impairment, and if the injury falls within the defined scope of neurological injuries, direct compensation by the fund, similar to a no-fault system). Similar bills have been introduced every year since 2001 .

131. Why the Birth-Injury Program, ViRginia BiRTh-Related NEUROLOGICAl INJURY COMPENSATION PROGRAM, at http://www.vabirthinjury.com/why-the-birth-injury-program/ (last visited Feb. 6, 2012).

132. Id.

133. The Florida BiRTh-Related NeUrological InJury COMPENSATION Program, at http://www.nica.com/what-is-nica.html/ (last visited Feb. 7, 2012) ("NICA ensures that birth-injured infants receive the care they need while reducing the financial burden on medical providers and families.").

134. For an early evaluation of Florida's program, see Jill Horwitz \& Troyen A. Brennan, No-Fault Compensation for Medical Injury: A Case Study, 14 HEALTH AFF. 164 (1995), available at http://content.healthaffairs.org/content/14/4/164.full.pdf.

135. Hodge, supra note 125, at 68. See also Rothstein, supra note 93, at 152 (noting that "the terms of its implementation would have to be carefully designed."). 
However, claimants seeking larger payouts might still choose to pursue litigation unless compensation pools were made the exclusive remedy. Moreover, it has been argued that creation of such a fund in the (very likely) instance of scarce resources in a pandemic could divert money and personnel from "providing care and conducting rescue, recovery, and rebuilding operations." " Nor is it clear how such a fund would be sustained.

\section{E. Judge, Court, and Attorney Education}

Although the New York Department of Health may intend for the Guidelines to establish the medical standard of care in a pandemic emergency, courts will not necessarily agree. ${ }^{137}$ Thus, special education, via Continuing Legal Education ("CLE") and Continuing Judicial Education ("CJE"), for judges, attorneys, and others who participate in the legal system may be necessary. Educating these professionals about the laws, guidelines, and policies that pertain to the provision of care in a declared emergency may better prepare them to consider and argue for crisis standards of care, provide tailored jury instructions and charges regarding appropriate conduct in an emergency, and perhaps reduce the liability risk to health care workers who provide care pursuant to the Guidelines.

New York State has already taken a step in this direction: a February 2010 New York State Bar Association CLE publication provides guidance for managing future public health disasters. ${ }^{138}$ A number of other states have also published "bench books" - compilations of materials for use by courts in the wake of pandemic influenza - to educate court employees (and specifically, judges) on resolving disputes that arise in a public health emergency, particularly with regard to issues regarding isolation and qua-

136. Hoffman, supra note 33, at 1968 .

137. New York common law allows for the consideration of the reasonableness of an individual's conduct when confronted with a sudden emergency situation. The common law emergency doctrine "recognizes that when an actor is faced with a sudden and unexpected circumstance which leaves little or no time for thought, deliberation or consideration, or causes the actor to be reasonably so disturbed that the actor must make a speedy decision without weighing alternative courses of conduct, the actor may not be negligent if the actions taken are reasonable and prudent in the emergency context." Rivera v. N.Y. City Tr. Auth., 77 N.Y.2d 322, 327 (1991). In such cases, the judge may provide special instructions to the jury that it may consider the reasonableness of a party's conduct in light of the unexpected emergency confronting that person. However, it should be noted that this doctrine has been "somewhat eroded by the evolution from contributory negligence to comparative negligence" in New York courts. Id. at 335.

138. New York State Public Health Legal Manual: A Guide for Judges, Attorneys and Public Health Professionals (Feb. 2010), available at http://www.nycourts.gov/whatsnew/pdf/PublicHealthLegalManual.pdf. The Manual was prepared in collaboration with the New York State Unified Court System, the New York State Bar Association, the New York State Department of Health, and the New York City Department of Health and Mental Hygiene. In the section entitled "Allocation of Resources in Disaster," the authors note that there are "[n]o applicable statutes or rules," but discusses the SDEA, Executive Law (including the Disaster Act), the federal PREP Act, and the federal VPA, in the Manual's consideration of statutory immunity from liability. Id. at 54-55. 
rantine and determination of jurisdiction and venue. ${ }^{139}$ Although most of these bench books do not address crisis standards of care, specific jury instructions, or other issues relevant to the allocation of scarce resources during a pandemic, they do provide a model for educating court employees for dealing with difficult emergency situations. ${ }^{140}$ Similarly, attorney education about the standard of care in a disaster emergency for providers and entities who follow the Guidelines would prepare hospital and physician insurance carrier attorneys, health care provider defense attorneys, and others to argue to judges and juries about the proper legal standard of care in the context of cases as they arise.

\section{CRIMINAL LIABILITY}

Recent events have underscored the need for systematic protection of health care providers and entities who follow a modified medical standard of care in a public health emergency. An oft-cited case illustrates the significance of providing criminal protections for health care workers who render care in a declared emergency. In the wake of Hurricane Katrina, Dr. Anna Maria Pou was arrested for the alleged murder of four elderly patients for whom she had provided palliative care at New Orleans' Memorial Medical Center, providing them with allegedly lethal dosages of

139. See, e.g., Florida Court Education Council, Pandemic Influenza Benchguide: Legal Issues Concerning Quarantine and Isolation, FLORIDA STATE COURTS (2007), at http://www.flcourts.org/gen_public/

courted/bin/pandemic_benchguide.pdf; Judicial Council of Georgia, Georgia Pandemic Influenza Bench Guide 2009, ADMINISTRATIVE OFFICE OF THE COURTS, at

http://www.georgiacourts.org/aoc/PandemicBenchGuideV1.pdf; Isolation and Quarantine Benchbook, MINNESOTA JUDICIAL BRANCH (Nov. 2008), at http://www.mncourts.gov/Documents/0/Public/

Isolation_and_Quarantine/Isolation_and_Quarantine_Benchbook.pdf; North Carolina Administrative Office of the Courts, Pandemic Emergency Bench Book for Trial Judges, UNC SCHOOL OF GovernMENT (Aug. 2009), at

http://www.sog.unc.edu/sites/www.sog.unc.edu/files/PandemicEmergencyBenchBook_Dec2009.pdf; Judge Robert P. Ringland, Public Health Preparedness Bench Book: A Guide for the Ohio Judiciary \& Bar on Legal Preparedness for Public Health Emergencies \& Routine Health Cases, SUPREME COURT OF OHIO, at http://www.supremecourt.ohio.gov/Boards/courtSecurity/PandemicPrepareGuide.pdf; Supreme Court of Virginia's Pandemic Flu Preparedness Commission, Pandemic Influenza Bench Book for Virginia's Court System, VIRGINIA's JUdicial SySTEM (2010), at

http://www.courts.state.va.us/programs/pfp/benchbook.pdf.

140. Arizona, Indiana, Kentucky, and Michigan are the only bench books that address immunity for responding in an emergency. See Daniel S. Strouse, Public Health Law Judicial Reference Guide for Arizona Courts, ARIZONA JUdicIAL BRANCH (2006) at

http://www.azcourts.gov/portals/84/MeetingMaterials/2006/06Dec/publichealthlaw.pdf; Michigan Office of the Attorney General, Public Health Law Bench Book for Michigan Courts (2007), at http://www.michigan.gov/documents/ag/Michigan_Public_Health_Bench_Book_221936_7.pdf; Center for Public Health Law Partnerships, University of Louisville, Public Health Law Bench Book for Kentucky Courts, Centers FOR DiSEASE CONTROL \& PREVENTION (2006), at http://stacks.cdc.gov/view/cdc/6815/; Center for Public Health Law Partnerships Institute for Bioethics, Health Policy and Law, University of Louisville School of Medicine, Public Health Law Bench Book for Indiana Courts, ADMINISTRATIVE OFFICE OF THE COURTS (2005), available at $\mathrm{http}: / /$ www.georgiacourts.org/aoc/r_p_docs/INBenchBook.pdf. 
morphine and midazolam so that they would not suffer pain. ${ }^{141}$ Although the grand jury declined to indict her on the murder counts, the threat of criminal liability will likely discourage other physicians, nurses, and health care professionals from deviating from standard non-emergency medical practice, even if done pursuant to state guidance, in a future emergency.

Because criminal liability must be proved "beyond a reasonable doubt," the standard for finding a health care provider guilty of criminal behavior is quite high. ${ }^{142}$ Regardless, this high burden of proof does not shield health care workers from prosecution. Thus, complying with the Guidelines in a severe pandemic could give rise to criminal liability claims by patients (or their families), particularly where health care workers withheld access to ventilators or extubated patients. ${ }^{143}$ Although legislative action could protect health care providers from criminal liability where they have appropriately followed the Guidelines, instituting protections for health care providers from criminal liability could be even more difficult than establishing broader civil liability protections, due to concerns about inadvertently sheltering intentional misconduct.

Currently, no New York law provides criminal immunity to health care providers in a state of emergency. ${ }^{144}$ In fact, only a handful of states provide criminal liability protections to health care providers during a disaster. $^{145}$

Although New York law does not confer immunity to providers and entities who provide care during a declared disaster emergency, New York State Public Officers Law Section 19 authorizes reimbursement for criminal defense expenses incurred by an "employee" - defined similarly to Section 17, although without the extension of Section 14 - in his or her defense of a criminal proceeding "arising out of any act which occurred while such employee was acting within the scope of his public employment or duties upon his acquittal or upon the dismissal of the criminal

141. Susan Okie, Dr. Pou and the Hurricane - Implications for Patient Care During Disasters, 358 NEw ENGL. J. MED. 1 (2008), available at http://www.nejm.org/doi/pdf/10.1056/NEJMp0707917.

142. See Gina Castellano, Note, The Criminalization of Treating End of Life Patients with Risky Pain Medication and the Role of the Extreme Emergency Situation, 76 FORDHAM L. REV. 203, 206 (2007).

143. See, e.g., Kenneth Kipnis, Forced Abandonment and Euthanasia: A Question from Katrina, 74 Soc. RES. 79 (2007)

144. See Thaddeus Mason Pope \& Mitchell F. Palazzo, Legal Briefing: Crisis Standards of Care and Legal Protections During Disasters and Emergencies, 21 J. CLIN. ETHICs 358-368, 362 (2010).

145. See, e.g., MD. PUB. SAFETY CODE ANN. § 14-3A-06 (2011) ("A health care provider is immune from civil or criminal liability if the health care provider acts in good faith and under a catastrophic health emergency proclamation.") (emphasis added). See also American College of Emergency Physicians, The National Report Card on the State of Emergency Medicine, http://www.emreportcard.org (last visited Feb. 12, 2013) (noting also that "New York has failed to enact reforms such as pretrial screening panels, a medical liability cap on non-economic damages, and expert witness rules that require the witness to be of the same specialty as the defendant, among others"). 
charges against him."146 The attorney general is empowered to determine, after investigation and review of the facts and circumstances of the criminal proceeding, whether the application for reimbursement should be granted. Thus, Section 19 is less extensive than Section 17, both in the protections it offers and who it protects. Further, as with Section 17, Section 19 may be inadequate to convince health care workers to follow the Ventilator Guidelines because it would not eliminate the burdens of a lawsuit.

It has been suggested that guidance from organizations (or, in this case, the Task Force and New York Department of Health) could be useful in criminal litigation for determining whether health care providers acted appropriately. ${ }^{147}$ However, evidence of reliance on the Guidelines would only serve as exculpatory evidence and therefore would not insulate a health care provider from criminal prosecution.

\section{CONCLUSION AND PROPOSALS FOR LEGISLATION}

Legislation granting at least civil (if not also criminal) liability protections to all health care workers and entities who follow New York State's Ventilator Guidelines in an influenza pandemic would provide the greatest assurance against liability and eliminate the patchwork approach to liability protections currently in effect. The establishment of binding immunity-conferring rules would go a long way toward encouraging physicians, nurses, and other health care workers, as well as hospitals and other health care entities, to comply with the Guidelines. ${ }^{148}$

Any legislation granting immunity to health care providers and entities that adhere to the Ventilator Guidelines should strike a balance between safeguarding patients and protecting all health care workers and entities. In particular, it should give special consideration to limitations such as good faith requirements and exclusions for certain acts of gross negligence or willful misconduct. Further, any legislation should eliminate the line between compensated employees, independent contractors, and unpaid or paid volunteers and should apply to all situations in which caregivers

146. N.Y. PUB. OFF. LAW $§ 19$ (McKinney 2012).

147. Hoffman, supra note 33, at 1962.

148. An underlying statutory or regulatory basis must be established for enforcement or mandated compliance - guidelines alone are insufficient. Greenberg, Statutory and Regulatory Authority Over OfficeBased Surgery, supra note 90. Notably, Greenberg states that "[d]eviation from the guidelines, however, does not necessarily create a prima facie case of negligence. Any such initiative in New York would require statutory authority." Id. Consequently, an attempt by the Department of Health to condition a determination of negligence or gross negligence on following the draft guidelines, absent legislation authorizing such an action, would be subject to legal challenge. Id. 
adhere to the Guidelines, regardless of the setting. ${ }^{149}$ Finally, liability protections should not be limited to only those health care workers who follow the clinical protocol presented in the Guidelines; protection should be extended to all those who provide, in good faith and in the absence of gross negligence, care in a disaster emergency. ${ }^{150}$

In the absence of legislation conferring full immunity, states should in the least consider the alternative approaches discussed in Section V to mitigate costs and burdens of lawsuits. While these protections are certainly less comprehensive than immunity-conferring legislation, they may be more politically palatable, and would have substantial impact on encouraging clinicians to adhere to triage protocols necessary to promote survival of the greatest number of people during a pandemic. Although the discussion in this article focused primarily on New York State law and policy, its analysis and recommendations may be extrapolated to other states and jurisdictions, in an effort to encourage compliance with local, state, and federal disaster plans and guidance.

149. This may also obviate Mark Rothstein's concern that immunizing only volunteers would create a distinction between (wealthy) patients of non-volunteer physicians and (indigent) patients of volunteer physicians in their access to legal recourse if they are harmed by substandard medical care. Rothstein, supra note 93 , at $151-52$.

150. No state has explicitly conferred liability protections for certain specified classes of actions taken by health care workers during an emergency, but instead they generally provide general protections for any care provided in good faith and in the absence of gross negligence. See, e.g., MD. PUB. SAFETY CODE ANN. § 14-3A-06 (2011); VA. CODE ANN. § 8.01-225.02 (2011); WYO. STAT. § 35-4-114 (2010) ("[A]ny health care provider or other person who in good faith follows the instructions of the state health officer in responding to the public health emergency is immune from any liability arising from complying with those instructions," excluding "acts or omissions constituting gross negligence or willful or wanton misconduct . . .."). 